\title{
Bioactive Peptides from Liquid Milk Protein Concentrate by Sequential Tryptic and Microbial Hydrolysis
}

\author{
Arijit Nath ${ }^{1, *}$, Attila Csighy ${ }^{1}$, Burak Attila Eren ${ }^{1}$ DD, David Tjandra Nugraha ${ }^{2}$, Klára Pásztorné-Huszár ${ }^{3}$, \\ Attila Tóth ${ }^{4}\left(\mathbb{D}\right.$, Krisztina Takács ${ }^{5}$, Emóke Szerdahelyi ${ }^{5}$, Gabriella Kiskó ${ }^{6}$, Zoltán Kovács ${ }^{2}$ (D) András Koris ${ }^{1}$ \\ and Gyula Vatai ${ }^{1, *}$
}

1 Department of Food Engineering, Institute of Food Science and Technology, Hungarian University of Agriculture and Life Sciences, Ménesi st 44, HU-1118 Budapest, Hungary; Csighy.Attila@uni-mate.hu (A.C.); Eren.Burak.Atilla@phd.uni-mate.hu (B.A.E.); Koris.Andras@uni-mate.hu (A.K.)

2 Department of Measurements and Process Control, Institute of Food Science and Technology, Hungarian University of Agriculture and Life Sciences, Somlói Street 14-16, HU-1118 Budapest, Hungary; tjandra.nugraha.david@hallgato.uni-szie.hu (D.T.N.); kovacs.zoltan.food@uni-mate.hu (Z.K.)

3 Department of Refrigeration and Livestock Products Technology, Institute of Food Science and Technology, Hungarian University of Agriculture and Life Sciences, Ménesi út 43-45, HU-1118 Budapest, Hungary; Pasztorne.Huszar.Klara@uni-mate.hu

4 Division of Clinical Physiology, Department of Cardiology, Faculty of Medicine, University of Debrecen, Móricz Zsigmond Str 22, HU-4032 Debrecen, Hungary; atitoth@med.unideb.hu

5 Food Science Research Group, Institute of Food Science and Technology, Hungarian University of Agriculture and Life Sciences, Herman Ottó út 15, HU-1022 Budapest, Hungary; takacs.krisztina@uni-mate.hu (K.T.); Nemethne.Szerdahelyi.Emoke@uni-mate.hu (E.S.)

check for updates

Citation: Nath, A.; Csighy, A.; Eren, B.A.; Tjandra Nugraha, D.; Pásztorné-Huszár, K.; Tóth, A.;

Takács, K.; Szerdahelyi, E.; Kiskó, G.; Kovács, Z.; et al. Bioactive Peptides from Liquid Milk Protein Concentrate by Sequential Tryptic and Microbial Hydrolysis. Processes 2021, 9, 1688. https://doi.org/10.3390/pr9101688

Academic Editor: Nevena Ilieva

Received: 14 June 2021

Accepted: 12 September 2021

Published: 22 September 2021

Publisher's Note: MDPI stays neutral with regard to jurisdictional claims in published maps and institutional affiliations.

Copyright: (c) 2021 by the authors. Licensee MDPI, Basel, Switzerland. This article is an open access article distributed under the terms and conditions of the Creative Commons Attribution (CC BY) license (https:/ / creativecommons.org/licenses/by/ $4.0 /)$.
6 Department of Food-Microbiology, Hygiene and Safety, Institute of Food Science and Technology, Hungarian University of Agriculture and Life Sciences, Somlói st 14-16, HU-1118 Budapest, Hungary; Kisko.Gabriella@uni-mate.hu

* Correspondence: arijit0410@gmail.com (A.N.); Vatai.Gyula@etk.szie.hu (G.V.); Tel.: +36-1-305-7110 (A.N.); +36-1-305-7115 (G.V.); Fax: +36-1-305-6323 (A.N.)

\begin{abstract}
Recently, bioactive peptides as a health-promoting agent have come to the forefront of health research; however, industrial production is limited, possibly due to the lack of the required technological knowledge. The objective of the investigation was to prepare bioactive peptides with hypoallergenic properties from liquid milk protein concentrate (LMPC), through sequential enzymatic and microbial hydrolysis. LMPC was produced from ultra-heat-treated (UHT) skimmed cow's milk using a nanofiltration membrane. The effect of the concentration of trypsin $\left(0.008-0.032 \mathrm{~g} \cdot \mathrm{L}^{-1}\right)$ on the hydrolysis of LMPC was studied. Subsequently, the hydrolysis of tryptic-hydrolyzed LMPC (LMPC-T) with lactic acid bacteria was performed, and the effect of glucose in microbial hydrolysis was studied. Aquaphotomic analysis of the hydrolysis of LMPC was performed using the spectral range of 1300-1600 nm (near-infrared spectra). Changes in antioxidant capacity, anti-angiotensinconverting enzyme activity, and antibacterial activity against Bacillus cereus, Staphylococcus aureus and Listeria monocytogenes were noted after the sequential tryptic and microbial hydrolysis of LMPC. Allergenicity in LMPC was reduced, due to sequential hydrolysis with $0.016 \mathrm{~g} \cdot \mathrm{L}^{-1}$ of trypsin and lacteal acid bacteria. According to the aquaphotomic analysis result, there was a dissociation of hydrogen bonds in compounds during the initial period of fermentation and, subsequently, the formation of compounds with hydrogen bonds. The formation of compounds with a hydrogen bond was more noticeable when microbial hydrolysis was performed with glucose. This may support the belief that the results of the present investigation will be useful to scale up the process in the food and biopharmaceutical industries.
\end{abstract}

Keywords: liquid milk protein concentrate; peptides; tryptic hydrolysis; microbial hydrolysis; antioxidant capacity; angiotensin-converting enzyme inhibitory activity; antibacterial activity; allergenic property; antigenic property; aquaphotomics 


\section{Introduction}

Metabolic syndrome is a cluster of biochemical, physiological and clinical abnormalities that leads to several health problems, such as cardiovascular diseases, obesity, dyslipidemia and noninsulin-dependent diabetes mellitus [1]. The circulatory hormone angiotensin, an important effector of the renin-angiotensin system, influences metabolic abnormality and is closely related to oxidative stress and inflammation [2]. Angiotensinconverting enzymes play a significant role in blood-pressure regulation, as well as cardiovascular disease. Due to the presence of an angiotensin-converting enzyme, angiotensin I is converted to angiotensin II in the renin-angiotensin pathway, which promotes vasoconstriction as well as high blood pressure [3]. The renin-angiotensin system also plays a key role in the activation of pro-inflammatory genes (nuclear factor- $\mathrm{\kappa} B$ regulated genes) and synthesis of pro-inflammatory substances (tumor necrosis factor- $\alpha$, interleukin- $1 \beta$, interleukin- 6 , interleukin- 8 , monocyte chemoattractant protein- 1 and transforming growth factor- $\beta$ ) through several biochemical mechanisms, and consequently increases oxidative stress that could damage cells and tissues [4-6]. Under stress conditions, angiotensin II stimulates the formation of reactive oxygen species, which reduce the formation and activity of endothelial nitrous oxide [7], mitochondrial membrane potential and the redox-sensitive activation of mitogen-activated protein kinase [8]. These lead to vascular inflammatory responses, the growth of vascular smooth muscle cells, the reduction of endothelium-dependent relaxation and cardiac hypertrophy [9]. Angiotensin II stimulates the synthesis of superoxides via the activation of $\mathrm{NAD}(\mathrm{P}) \mathrm{H}$ oxidase, which increases the risk of vascular disease $[10,11]$. In the heart, angiotensin II promotes the synthesis of pro-inflammatory substances through the release of aldosterone [12]. Angiotensin II downregulates the activity of peroxisome proliferator-activated receptors, which have many anti-inflammatory effects [5]. Locally synthesized angiotensin II decreases blood supply to adipose depots, encourages the clearance of released free fatty acids, and increases the appearance of local inflammation [13]. From the above discussion, it may appear that the modulation of the activity of the reninangiotensin-aldosterone system can reduce the complications of metabolic syndrome. Various drugs, categorized as an angiotensin-converting enzyme inhibitor, angiotensin II receptor blocker, and renin blocker, are meticulously assigned; however, different adverse side effects have been reported [14]. Recently, great attention has been placed on developing food-derived bioactive peptides, with anti-angiotensin activity and antioxidant capacity, as an alternative treatment in the management of metabolic syndrome [15].

Oxidative stress is also likely associated with a bacterial infection. Bacterial infections induce the formation of reactive oxygen and nitrogen species in uncontrolled ways and consequently activate pro-inflammatory mediators through altered metabolic pathways, where myeloperoxidase, NADPH oxidase, nitric oxide synthase, cytochrome P450 and xanthine oxidase are involved [16]. It modulates the antioxidant defense system and may cause organ damage and malignancies, which promotes cellular death (necrosis) [17]. Despite the considerable advancement of a wide variety of antibiotics and their availability for the treatment of microbial infection, there is an argument regarding the dangers of multidrug-resistant bacteria [18]. The long-term consumption of antibiotics may alter cellular respiration and induce a lethal level of intracellular reactive oxygen and nitrogen species, as part of their mechanism of action [19]. In a comparison of effectivity between bioactive peptides and synthetic pharmaceutical antibiotics, bioactive peptides received a high score, due to their biocompatible characteristics without serious side effects [20]. Peptides with antibacterial activity could play a prominent role in maintaining the balance of reactive oxygen species in an inflammatory environment. Recent scientific studies proved that antimicrobial peptides have immunomodulatory properties, capable of regulating both anti-inflammatory and pro-inflammatory activities [21].

The abundance of protein molecules in nature, in both edible and non-edible forms, encourages researchers to produce bioactive peptides because it is well-recognized that bioactive peptides offer beneficial physiological effects and reduce the risk factors of several diseases. The biological activities of peptides depend on their bioavailability and absorption 
in intact forms to the target cells and tissues, which in turn depends on the structure (length and amino acid sequence) of peptides. Therefore, the selection of native proteins to develop bioactive peptides is a particularly interesting issue [22]. Milk is a source of an abundant number of proteins with unique biological properties, and is available around the globe, throughout the year. The hydrolysis of milk proteins, such as micellar casein, $\alpha$-lactalbumin, $\beta$-lactoglobulin, immunoglobulin, bovine serum albumin, lactoferrin, lactoperoxidase and glycomacropeptide, with proteases producing amino acids and dietary peptides that offer several functional capabilities [23]. On the other hand, milk proteins are listed among the "big 8" allergens, due to the presence of linear and conformational epitopes [24]. To satisfy the demand for peptides from milk proteins in the food and biopharmaceutical industries, several approaches were addressed [25]. The development of dietary dairy-based peptides with unique functional value through a biochemical route may be referred to as "safe" because toxic byproducts are not generated during bioprocessing [22]. However, several investigations have been made into the development of bioactive peptides from milk proteins by enzymatic or microbial hydrolysis processes, and there are several challenging issues in that context. Due to considerable heterogeneities among epitopes (linear and conformational epitopes) in milk proteins, a suitable strategy for their reduction is a notably challenging issue [26]. In many cases, the limited enzymatic or microbial hydrolysis of proteins produces new antigenic peptides [27]. To reduce the allergenicity of milk proteins in an intense way requires a high concentration of enzymes in the proteolysis reaction. Without a doubt, this increases the overall processing cost. The selection of enzymes for the hydrolysis of milk proteins is a considerable challenge. In protein structures, the activity of exopeptidase is random and, as a result, amino acids and di-peptides are produced. However, the activity of endopeptidase in the protein structure is preferential. Therefore, peptides with unique biological activities are produced by the catalytic activity of endopeptidase. The activity of proteolytic enzymes alters their fluid and organoleptic properties [28,29]. Furthermore, the cost of the downstream process, developed using membrane-based filtration and chromatography to isolate the targeted peptide from the reaction mixture, increases the overall processing cost [30].

From the above discussion, it is clear that an attempt is needed to produce peptides with antioxidant capacity, anti-angiotensin activity, antimicrobial activity and hypoallergenic properties from milk proteins through the biochemical route. The objective of this investigation was to prepare peptides with the abovementioned biochemical potentialities via the sequential tryptic and microbial (lactic acid bacteria) hydrolysis of liquid milk protein concentrate (LMPC). At the end of the fermentation process, the fermentation broth was centrifuged, and the supernatant was considered as a source of peptides with antioxidant capacity, anti-angiotensin activity, antimicrobial activity and hypoallergenic properties. It may be assumed that this cluster of peptides with different functional activities possibly enhances the overall biological activity. Therefore, in this investigation, membrane- and chromatography-based downstream processing were not employed to isolate individual peptides. Additionally, this may reduce the overall processing cost. Aquaphotomics, a new approach, was considered as a vehicle to understand the change of the $\mathrm{O}-\mathrm{H}$ bond during the tryptic and microbial hydrolysis processes.

\section{Materials and Methods}

\subsection{Ultra-Heat-Treated (UHT) Skimmed Cow's Milk}

UHT skimmed cow's milk, with concentrations of protein, lactose, and fat of $29.5 \mathrm{~g} \cdot \mathrm{L}^{-1}$, $45 \mathrm{~g} \cdot \mathrm{L}^{-1}$, and $1 \mathrm{~g} \cdot \mathrm{L}^{-1}$, respectively, was procured from local supermarkets in and around Budapest, Hungary. The $\mathrm{pH}$ of the milk was 6.8 at room temperature $(\mathrm{RT})\left(\sim 25^{\circ} \mathrm{C}\right)$. In the present investigation, UHT skimmed milk was used because its shelf-life is much better compared to extended shelf-life milk or unheated natural milk. Furthermore, the chance of the coagulation of proteins in UHT milk due to the application of trypsin and microbial proteolysis is negligible, compared to extended shelf-life milk and unheated natural milk [28]. 


\subsection{Production of Peptides with Functional Values from LMPC}

Peptides with antioxidant capacity, angiotensin-converting enzyme inhibitory activity, antibacterial activity, and hypoallergenic properties, were prepared by the sequential tryptic and microbial hydrolysis of LMPC. In Figure 1, the experimental scheme for the preparation of peptides with the abovementioned biological activities is represented.

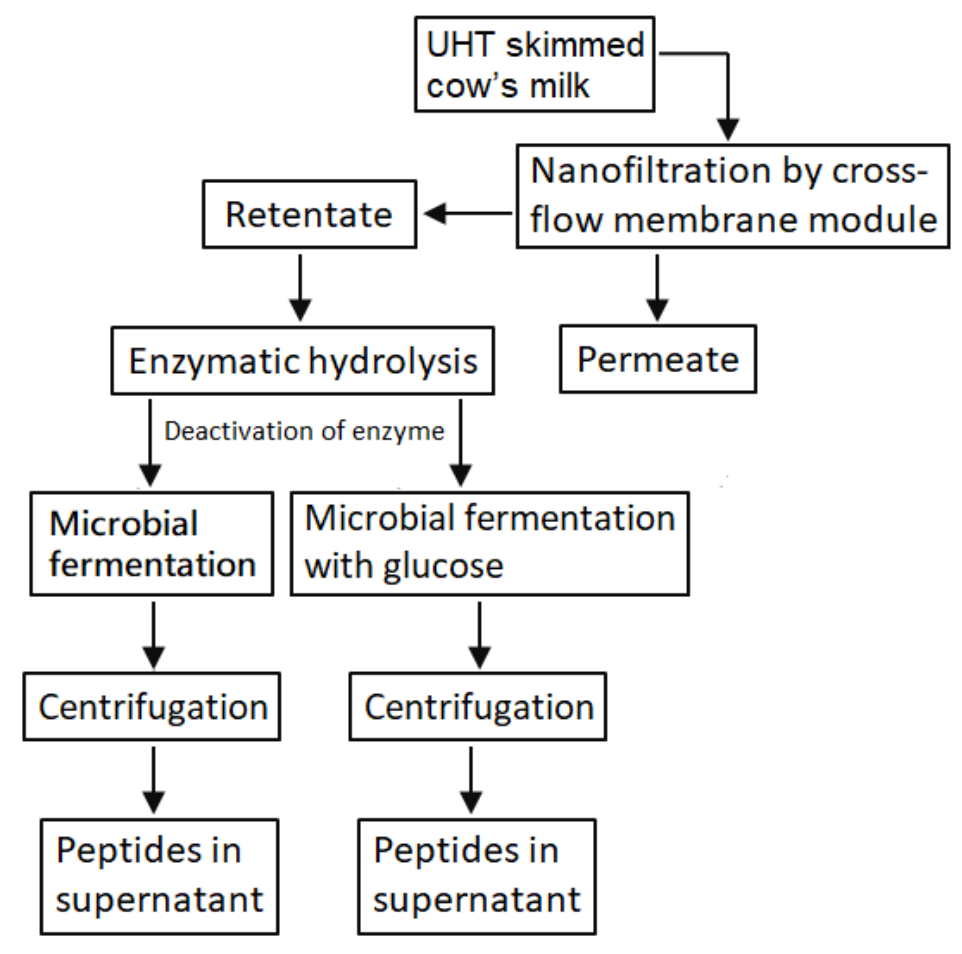

Figure 1. Experimental scheme to prepare peptides with antioxidant capacity, angiotensin-converting enzyme inhibitory activity, antibacterial activity and hypoallergenic properties from skimmed UHT cow's milk.

\subsubsection{Preparation of LMPC}

A ceramic-made tubular nanofiltration membrane with a pore size of $5 \mathrm{~nm}$ (Pall Corporation, Crailsheim, Germany) was adopted to prepare LMPC from UHT skimmed cow's milk. The membrane was placed in a stainless steel-made crossflow membrane module. A static turbulence promoter was placed inside the membrane tube. Detailed descriptions of the membrane module, tubular membrane and static turbulence promoter have been mentioned in a previous publication [23]. The membrane filtration process was performed with trans-membrane pressure at $3 \mathrm{bar}$, a retention flow rate of $100 \mathrm{~L} \cdot \mathrm{h}^{-1}$, and a volume reduction factor of 2 at RT. The volume reduction factor during the filtration process was maintained in two different ways:

(1) The feed tank of the membrane module was filled with 1.4 L of UHT skimmed cow's milk, prior to starting the filtration, and $700 \mathrm{~mL}$ of permeate was collected.

(2) The feed tank of the membrane module was filled with $800 \mathrm{~mL}$ of UHT skimmed cow's milk, prior to starting the filtration, and a constant volume of permeate, i.e., $100 \mathrm{~mL}$, was collected. After the collection of $100 \mathrm{~mL}$ of permeate, another $100 \mathrm{~mL}$ of milk was supplied to the feed tank to maintain the volume level in the feed tank. In that way, to maintain the volume reduction factor of 2, in total, $600 \mathrm{~mL}$ of milk was supplied to the feed tank and a total of $700 \mathrm{~mL}$ of permeate was collected at the end of the experiment.

The permeate flux was calculated, based on Equation (1):

$$
J=V /(A \times t)
$$


where $J=$ permeate flux during filtration $\left(\mathrm{L} \cdot \mathrm{m}^{-2} \cdot \mathrm{h}^{-1}\right), V=$ volume of permeate $(\mathrm{L})$, $A=$ active membrane filtration area $\left(\mathrm{m}^{2}\right)$, and $t=$ filtration time (h) [23].

Furthermore, after the volume reduction factor of 2 , the reduction of permeate flux was calculated, based on Equation (2):

$$
\Delta J(\%)=\left(J_{\text {initial }}-J_{\text {final }}\right) \times 100 / J_{\text {initial }}
$$

After the filtration experiment, membrane cleaning was performed with Ultrasil P3-11 (Ecolab-Hygiene Kft, Budapest, Hungary), citric acid ( $\geq 99 \%$, Merck, Darmstadt, Germany) and Milli-Q ultrapure deionized water $(18.2 \mathrm{M} \Omega \cdot \mathrm{cm})$ in sequence. The detailed methodology is described elsewhere [23]. Milli-Q ultrapure deionized water was obtained from the Milli-Q Synergy/Elix water purification system (Merck-Millipore, Molsheim, France).

\subsubsection{In Vitro Hydrolysis of LMPC by Trypsin}

After achieving a volume reduction factor of 2 in the membrane filtration process, LMPC was collected from the storage tank of the membrane module. $3 \mathrm{~mL}$ of LMPC was pre-incubated in $5 \mathrm{~mL}$ of a polymer inkjet 3D-printed cuboid bioreactor. The length, width and height of the bioreactor were $1.0 \mathrm{~cm}, 1.45 \mathrm{~cm}$, and $3.5 \mathrm{~cm}$, respectively. A temperature and a pH sensor (Testo 206-pH1, Testo-AG, Reutlingen, Germany) were inserted into the bioreactor through a friction-fit lid. The bioreactor, along with the sensors, was placed at a temperature of $40{ }^{\circ} \mathrm{C}$ in an incubator (HACH, Düsseldorf, Germany), where an individual batch-mode tryptic hydrolysis reaction was performed with different concentrations of trypsin (T1426, Sigma-Aldrich, Schnelldorf, Germany), e.g., $0.008 \mathrm{~g} \cdot \mathrm{L}^{-1}, 0.016 \mathrm{~g} \cdot \mathrm{L}^{-1}$ and $0.032 \mathrm{~g} \cdot \mathrm{L}^{-1}$. These are represented by LMPC-T-0.008, LMPC-T-0.016 and LMPC-T-0.032, respectively. For that purpose, when the temperature of LMPC reached $40{ }^{\circ} \mathrm{C}, 2.7 \mu \mathrm{L}$, $5.4 \mu \mathrm{L}$ and $10.8 \mu \mathrm{L}$ of trypsin solution from the stock solution of trypsin $\left(0.009 \mathrm{~g} \cdot \mathrm{mL}^{-1}\right)$ was inoculated into the LMPC through a sterile polyethersulfone (PES) syringe filter with a pore size of $0.2 \mu \mathrm{m}$ (VWR International, Radnor, PA, USA). The tryptic hydrolysis reaction was performed at a temperature of $40{ }^{\circ} \mathrm{C}$ for $10 \mathrm{~min}$ in an incubator $(\mathrm{HACH}$, Düsseldorf, Germany). After 10 min of the tryptic hydrolysis reaction, the bioreactor was immediately placed in a thermostat for the deactivation of trypsin activity. It was performed at a temperature of $70{ }^{\circ} \mathrm{C}$ for $30 \mathrm{~min}$ of incubation in a water bath [23]. Continuous scanning during trypsin-catalyzed hydrolysis was performed within a wavelength range of 900-1700 nm (NIR spectra), every minute, for the aquaphotomics analysis. Furthermore, the temperature and $\mathrm{pH}$ of the reaction medium were recorded, every minute, during the tryptic hydrolysis reaction.

\subsubsection{Microbial Hydrolysis}

After the de-activation of trypsin, the temperature of LMPC was reduced to $45^{\circ} \mathrm{C}$ in a laminar flow chamber. The effect of glucose in the microbial hydrolysis of LMPC and LMPC$\mathrm{T}$ was studied. For that purpose, $240 \mu \mathrm{L}$ of sterile glucose solution from $40 \%$ glucose stock solution was added to $3 \mathrm{~mL}$ of LMPC and LMPC-T separately, under aseptic conditions. As before, temperature and $\mathrm{pH}$ sensing probes (Testo 206-pH1, Testo-AG, Reutlingen, Germany) were inserted into the fermentation medium to record the temperature and $\mathrm{pH}$ of the fermentation medium at every minute during the fermentation process. Each sample was preincubated in an incubator (HACH, Düsseldorf, Germany) to reach a temperature of $45^{\circ} \mathrm{C}$. Lactic acid bacteria (Thermophilic YoFlex ${ }^{\circledR}$ Mild 1.0, Chr. Hansen, Nienburg, Germany) were used for the microbial hydrolysis of the protein concentrate. $30 \mu \mathrm{L}$ of the inoculum from the stock culture was inoculated into each individual sample. After inoculation, Streptococcus thermophilus and Lactobacillus bulgaricus were $5.5 \times 10^{6} \mathrm{CFU} \cdot \mathrm{mL}^{-1}$ and $1.5 \times 10^{7} \mathrm{CFU} \cdot \mathrm{mL}^{-1}$, respectively, in the fermentation medium, according to Breed's method [31]. Fermentation was performed at a temperature of $45^{\circ} \mathrm{C}$ for $6 \mathrm{~h}$ in an incubator (HACH, Düsseldorf, Germany) [32]. Fermented samples were represented by LMPCF, LMPC- $\mathrm{F}_{\mathrm{G}}$, LMPC-T-F and LMPC-T-F $\mathrm{G}_{\mathrm{G}}$. As before, continuous scanning during the 
microbial fermentation process was performed using a wavelength range of 900-1700 nm (NIR spectra) at every minute, for aquaphotomics analysis.

\subsection{Analytical Methods}

\subsubsection{Understanding the Molecular Weight Distribution of Proteins and Peptides}

Sodium dodecyl sulfate-polyacrylamide gel electrophoresis (SDS-PAGE) was performed according to the Laemmli method [33] to identify the molecular weight of proteins and peptides in LMPC, LMPC-T, LMPC-F, LMPC-F ${ }_{\mathrm{G}}$, LMPC-T-F and LMPC-T-F ${ }_{\mathrm{G}}$. In the vertical electrophoresis system, the concentrations of running gel and stacking gel were $15 \%$ and $6 \%$, respectively. A standard protein marker from Bio-Rad (Bio-Rad, Hercules, CA, USA) was used to determine the molecular weight of proteins and peptides. The detailed methodology is described in Supplementary Section.

\subsubsection{Immunoblotting}

Proteins and peptides from SDS-PAGE gel were transferred onto a polyvinylidene difluoride (PVDF) membrane. Trans-blot semi-dry transfer cells (Bio-Rad, CA, USA) were used in the experiment. Cow's milk positive pooled human serum and rabbit $(\mathrm{Rb})$ polyclonal sera were used to identify the allergenicity and antigenicity, respectively, in the samples [34]. The experimental method is described in detail in Supplementary Section.

\subsubsection{Determination of Protein Concentration}

Prior to assay, the samples, such as LMPC, LMPC-T, and the corresponding fermented broths with or without glucose, were centrifuged with a temperature-controlled laboratory centrifuge (Z206A; Wehingen, Germany). Centrifugation was performed at 10,000 rpm for $20 \mathrm{~min}$ at a temperature of $4{ }^{\circ} \mathrm{C}$, and the concentration of protein in supernatants was measured with a Bradford assay [35]. Details of the experimental protocol are given in Supplementary Section.

\subsubsection{Determination of the Antioxidant Capacity}

Ferric Reducing Ability of Plasma (FRAP) Assay

As before, all samples were centrifuged in a laboratory centrifuge (Z206A; Wehingen, Germany). The operating conditions for centrifugation were as mentioned earlier. The antioxidant capacity of supernatants was measured using the ferric-reducing ability of plasma, considering ascorbic acid as a standard [36]. A detailed experimental protocol is given in Supplementary Section.

\section{2,2-Diphenyl-1-picrylhydrazyl (DPPH) Radical-Scavenging Assay}

Supernatants of all samples were received by centrifugation, performed under the abovementioned operating conditions. The antioxidant capacity in supernatants was measured using the DPPH radical-scavenging assay [37]. The experimental protocol is described in detail in Supplementary Section.

\subsubsection{Estimation of Angiotensin-Converting Enzyme Inhibitory Activity}

As before, all samples were centrifuged and the angiotensin-converting enzyme inhibitory activity was measured in the supernatants, as described earlier [38], with small modifications. The substrate Abz-FRK(Dnp)-P, the recombinant angiotensin-converting enzyme, and supernatants of the milk samples and corresponding fermentation broth were used to determine the $\mathrm{IC}_{50}$ values of samples. The activity of the angiotensin-converting enzyme in the absence of the supernatants of the samples was used to define uninhibited activity. The reaction was initiated by the addition of the substrate. The level of inhibition was calculated as the percentage of uninhibited activity in each plate. Activity values were fitted by nonlinear fits to yield the $K_{M}$ and $V_{\max }$ values. The experimental protocol is described in detail in Supplementary Section. 


\subsubsection{Microbiological Assay}

Antibacterial activity of all samples against Bacillus cereus, Staphylococcus aureus ATCC 6538 and Listeria monocytogenes CCM 4699 was investigated. All samples were centrifuged using the abovementioned operating conditions. The agar-well diffusion method was used for the investigation, as per [23]. The detailed experimental method is given in Supplementary Section.

\subsubsection{Near Infrared (NIR) Spectroscopy and Aquaphotomics Analysis}

Scanning was performed during the tryptic and microbial hydrolysis of LMPC, with a wavelength range of 900-1700 $\mathrm{nm}$ at every minute by an NIR-S-G1 handheld spectrophotometer (InnoSpectra Co., Hsinchu, Taiwan). The spectral data were pre-treated to reduce spectral noise and baseline variations, using the Savitzky-Golay (SG) [39] and standard normal variate (SNV) methods [40]. For the aquaphotomics analysis, the spectral data were truncated specifically in the wavelength range of 1300-1600 nm, and a star-shaped aquagram was created from the spectral data to visualize the spectral pattern changes [41]. The detailed information is given in Supplementary Section. The spectral evaluation was performed using the R-project statistical software (ver. 3.6.3, R Core Team, Vienna, Austria) [42], along with the "aquap2" package, as specified for the aquaphotomics and spectral analyses [43].

\subsection{Statistical Analysis}

SPSS 15.0 (IBM, Armonk, NY, USA) was used for the statistical analysis. All laboratory experiments were performed at least 3 times; subsequently, the mean values with standard deviation were calculated. A one-way analysis of variance (ANOVA) method, followed by Tukey's post hoc test, was adopted to determine the significant differences among the various groups. A significant difference was considered to be found when $p<0.05$.

\section{Results and Discussions}

\subsection{Preparation of LMPC}

LMPC was prepared from UHT skimmed cow's milk; it was collected from the retentate channel of the membrane module after the collection of $700 \mathrm{~mL}$ of permeate. Two different approaches have been adopted in the filtration process, as mentioned in Section 2.2.1. In Figure 2A, the permeate flux with time progression is represented, when the feed tank of the membrane module had been filled with $1.4 \mathrm{~L}$ of milk, prior to starting the filtration process, and once $700 \mathrm{~mL}$ of the permeate had been collected. In that case, the total filtration time, the reduction of the permeate flux from the initial flux, and the concentration of total protein in LMPC are $5.5 \mathrm{~h}, 34 \%$, and $51 \mathrm{~g} \cdot \mathrm{L}^{-1}$, respectively. In Figure $2 \mathrm{~B}$, the permeate flux with time progression is represented, when the feed tank of the membrane module had been filled with $800 \mathrm{~mL}$ of milk, prior to starting the filtration process; each time, $100 \mathrm{~mL}$ of milk was added after the collection of $100 \mathrm{~mL}$ of permeate, to eventually obtain $700 \mathrm{~mL}$ of permeate. Therefore, the total filtration time, the reduction of permeate flux from the initial flux, and the total concentration of protein in LMPC are $4.9 \mathrm{~h}$, $22 \%$, and $56 \mathrm{~g} \cdot \mathrm{L}^{-1}$, respectively.

In this investigation, the size of the protein molecule has a great impact on the rejection of protein molecules and permeate flux. Membrane filtration is a pressure-driven size-exclusion-based separation process. During filtration, the higher deposition of solutes on the membrane surface creates a cake layer, which gives the attributes of a higher mass transfer coefficient and membrane resistance. It reduces the permeate flux over the passage of time [44]. During the preparation of UHT skimmed cow's milk, with a temperature of $135-145^{\circ} \mathrm{C}$ and treatment exposure time of $1-8 \mathrm{~s}$, the sizes of the proteins in milk are changed, compared to their conventional sizes [45]. When milk is heated at a temperature above $80^{\circ} \mathrm{C}$, the tertiary structure of whey proteins begins to unfold, and denaturation takes place [46]. At that temperature and a shorter temperature exposure time, the disintegration of the casein micelles takes place in a partial way due to dephosphorylation [47]. 
Subsequently, the broken/denatured whey proteins bind among themselves [48], or bind with dephosphorylated or disintegrated casein molecules, especially with $\mathrm{k}$-casein, which is present in the periphery of the casein micelle by thiol/disulfide interchanges and hydrophobic interactions [49]. Hence, it can be supposed that most of the whey proteins attempt to bind with the casein micelles, and the size of casein micelles may increase. Furthermore, because of the intermolecular conjugation of whey proteins, the size of the whey proteins may increase. The biochemical mechanism of the conformational modification of proteins during the heat-treatment of skimmed cow's milk is represented in Figure 3A.
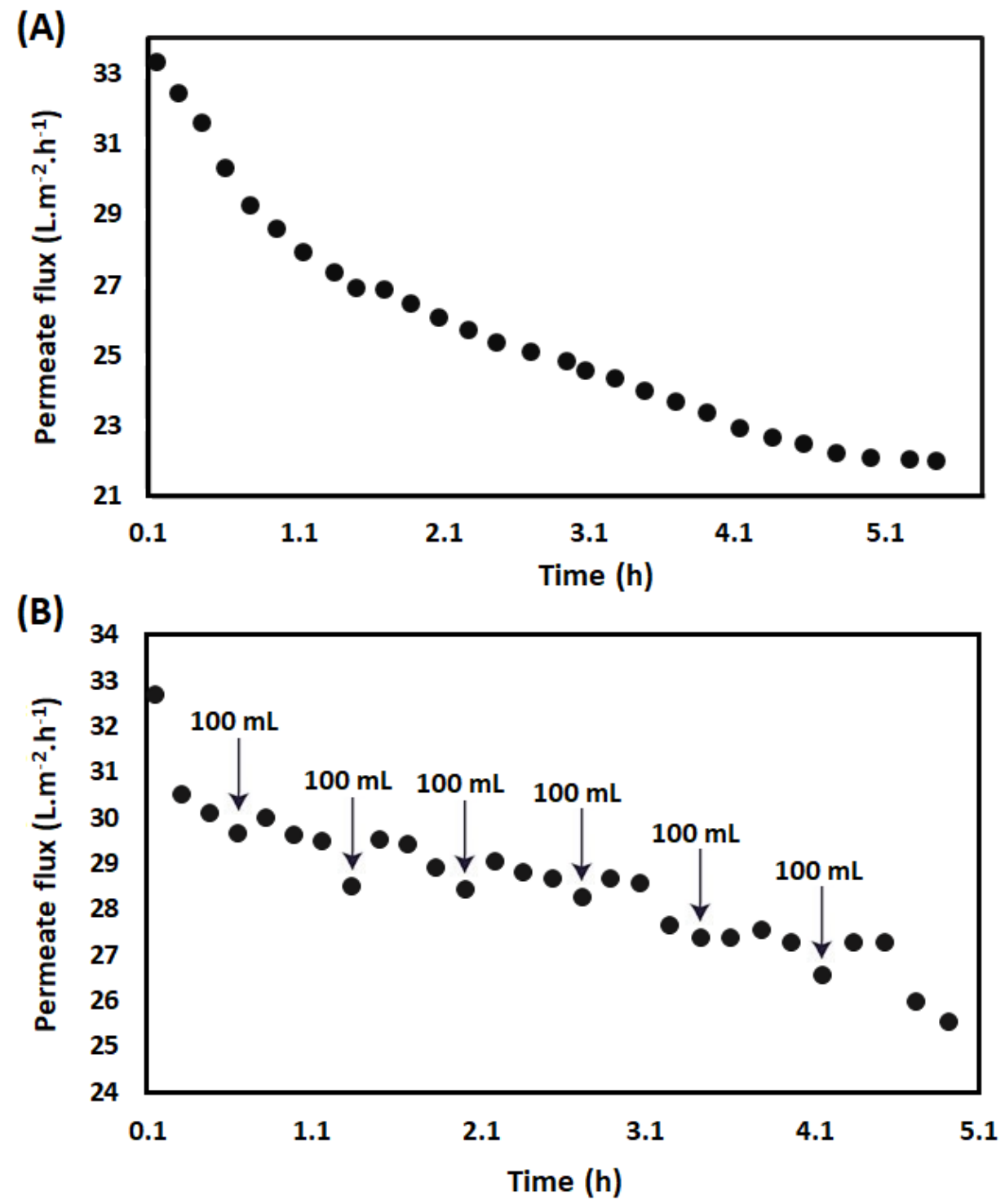

Figure 2. Permeate flux with the filtration time progression, (A) without the addition of milk in the feed tank in the intermediate steps of the filtration process, and (B) with the addition of milk in the feed tank in the intermediate steps of the filtration process.

Therefore, most of the proteins in UHT skimmed milk have been rejected by the membrane, and residual (unbounded) whey proteins and lactose have permeated through the membrane pores during filtration (Figure 3B). Due to the addition of milk in a continuous way to the feed tank, the deposition of solute molecules on the membrane surface was low. As a result, the reduction of permeate flux was low compared to the filtration process, without the addition of milk in an intermediate way. 


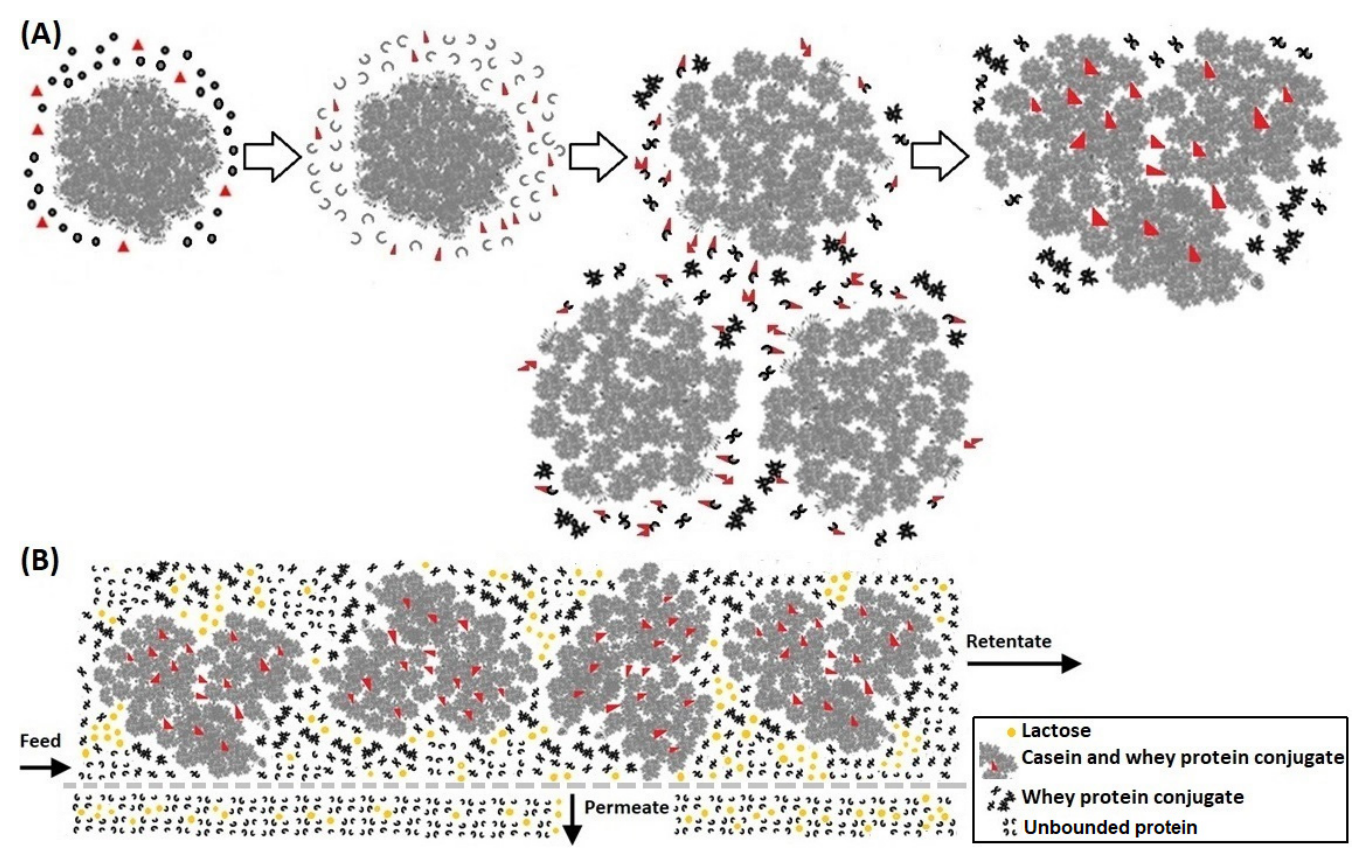

Figure 3. Schematic representation of the conformational modification of proteins during the heattreatment of skimmed cow's milk (A) (self-developed; the concept was adopted from Vasbinder et al., 2004 [50]); and the production of LMPC from UHT skimmed cow's milk by membrane filtration (B) (graphic self-developed; the concept was adopted from Li et al., 2015 [51]).

\subsection{Hydrolysis of Proteins in LMPC}

SDS-PAGE has been used to elucidate the hydrolysis of milk proteins by trypsin and microbial fermentation (Figure 4).

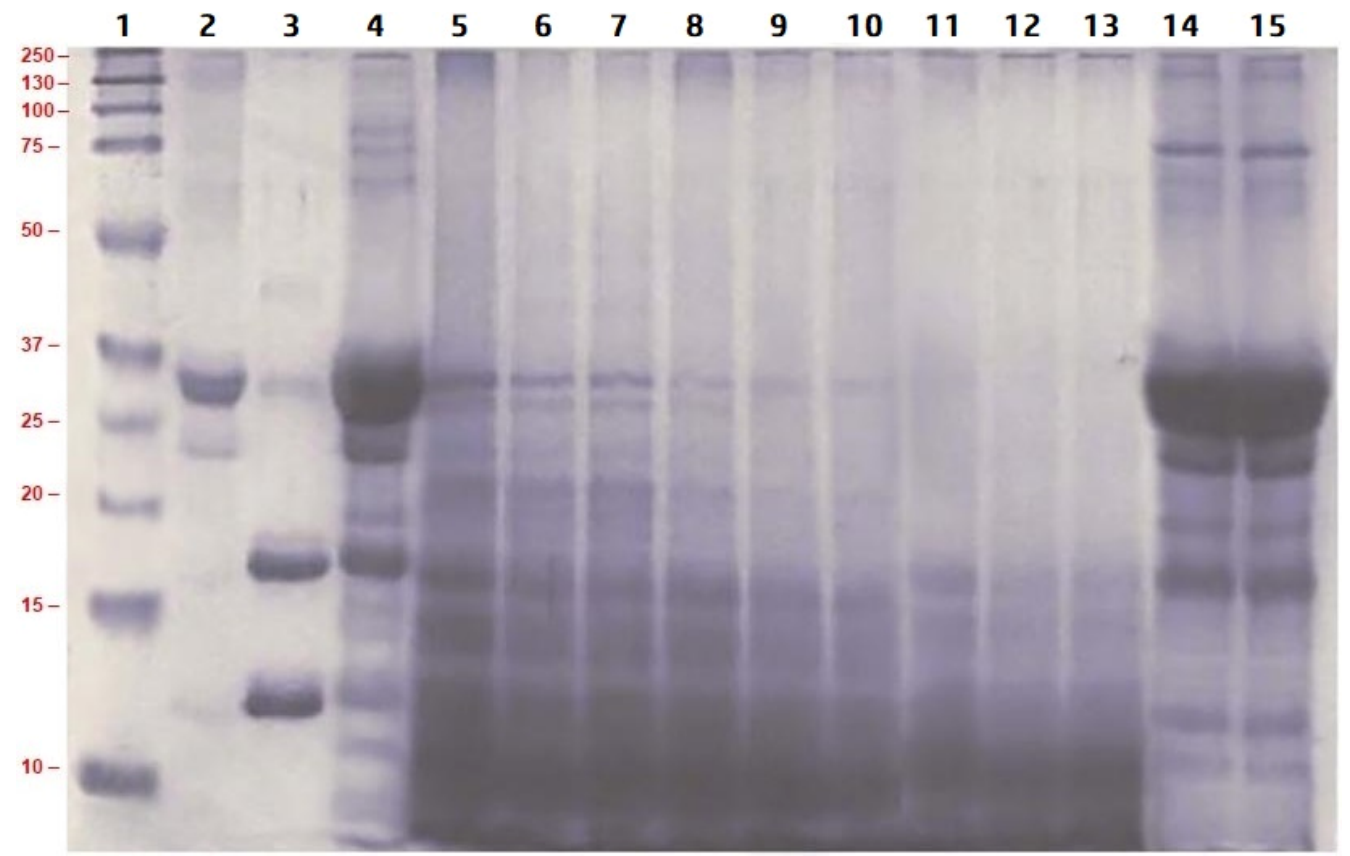

Figure 4. SDS-PAGE image of proteins and peptides; lane 1: marker protein, lane 2: standard casein, lane 3: standard $\alpha$-lactalbumin and $\beta$-lactoglobulin, lane 4: LMPC, lane 5: LMPC-T-0.008, lane 6: LMPC-T-0.008-F, lane 7: LMPC-T-0.008- $\mathrm{F}_{\mathrm{G}}$, lane 8: LMPC-T-0.016, lane 9: LMPC-T-0.016-F, lane 10: LMPC-T-0.016- $\mathrm{F}_{\mathrm{G}}$, lane 11: LMPC-T-0.032, lane 12: LMPC-T-0.032-F, lane 13: LMPC-T-0.032-F lane 14: LMPC-F, lane 15: LMPC-F . 
It can be seen that LMPC has immunoglobulin, lactoferrin, lactoperoxidase, bovine serum albumin, $\alpha$-casein, $\beta$-casein, $\mathrm{k}$-casein, $\beta$-lactoglobulin and $\alpha$-lactalbumin, with a molecular weight of $\sim 150 \mathrm{kDa}, \sim 80 \mathrm{kDa}, \sim 78 \mathrm{kDa}, \sim 66 \mathrm{kDa}, \sim 25 \mathrm{kDa}, \sim 24 \mathrm{kDa}, \sim 20 \mathrm{kDa}$, $\sim 18 \mathrm{kDa}$ and $\sim 14 \mathrm{kDa}$, respectively. Furthermore, a protein band with a molecular weight of $\sim 37 \mathrm{kDa}$ is shown in the SDS-PAGE image. This might be a dimer of $\beta$-lactoglobulin, or conjugated $k$-casein and $\alpha$-lactalbumin, or conjugated $\beta$-lactoglobulin and $\alpha$-lactalbumin. Heat-induced protein conjugation or aggregation has been reported by several researchers. At temperatures above $80^{\circ} \mathrm{C}$, whey proteins, such as $\alpha$-lactalbumin and $\beta$-lactoglobulin, begin to unfold and, subsequently, they can bind with $\mathrm{K}$-casein, as present in the periphery of the casein micelle $[47,49]$. Other investigators have reported that $\beta$-lactoglobulin may form a dimer by a disulfide bond when it is heated to a temperature higher than $75{ }^{\circ} \mathrm{C}[46,47]$. Furthermore, it has been reported that, due to heat treatment, $\alpha$-lactalbumin and $\beta$-lactoglobulin may produce covalently bonded hydrophobic aggregate as a result of the intermolecular thiol-disulfide bond interchange $[46,48]$.

In the SDS-PAGE image, it can be seen that the hydrolysis of milk proteins and formation of peptides with lower molecular weight are increased gradually, due to the tryptic digestion of proteins in LMPC (lane 5, lane 8, and lane 11). Trypsin is a serine endopeptidase that cleaves specifically at the carboxyl-terminal side of lysine and arginine amino acid residues, except in the case of lysyl-proline and arginyl-proline bonds in the amino acid chain. Immunoglobulin is almost hydrolyzed when the concentration of trypsin is $0.032 \mathrm{~g} \cdot \mathrm{L}^{-1}$. Lactoferrin, lactoperoxidase and bovine serum albumin are almost hydrolyzed, due to treatment with $0.008 \mathrm{~g} \cdot \mathrm{L}^{-1}$ of trypsin. Protein conjugate with a molecular weight of $\sim 37 \mathrm{kDa}$ is hydrolyzed in a significant way when the concentration of trypsin is $0.016 \mathrm{~g} \cdot \mathrm{L}^{-1}$. However, $\alpha$-casein is almost hydrolyzed with $0.032 \mathrm{~g} \cdot \mathrm{L}^{-1}$ of trypsin, and $\beta$-casein and $\kappa$-casein are largely hydrolyzed when the concentration of trypsin is $0.016 \mathrm{~g} \cdot \mathrm{L}^{-1}$. This can be explained by the fact that $\alpha$-casein presents in the interior part of casein micelle and might have less opportunity to interact with the catalytic site of trypsin, whereas $\mathrm{K}$-casein presents in the periphery of the casein micelle and is easily hydrolyzed by trypsin [49]. The tryptic hydrolysis of $\beta$-casein may produce $\gamma$-casein with a molecular weight fraction of $\sim 23 \mathrm{kDa}, \sim 16 \mathrm{kDa}$ and $\sim 11 \mathrm{kDa}$ [52]. In lane 5 and lane 8 , fragments of $\gamma$-casein with a molecular weight of $\sim 23 \mathrm{kDa}$ and $\sim 16 \mathrm{kDa}$ are clearly visible. However, the fragment of $\gamma$-casein with a molecular weight of $\sim 23 \mathrm{kDa}$ is almost hydrolyzed with the concentration of trypsin at $0.032 \mathrm{~g} \cdot \mathrm{L}^{-1} ; \beta$-lactoglobulin and the fragment of $\gamma$-casein with a molecular weight of $\sim 16 \mathrm{kDa}$ are retained when the concentration of trypsin is $0.032 \mathrm{~g} \cdot \mathrm{L}^{-1}$.

In lane 6 and lane 7, proteins and peptides, present in LMPC-T-0.008-F and LMPC-T$0.008-\mathrm{F}_{\mathrm{G}}$, are shown. It is observed that the protein conjugate with a molecular weight of $\sim 37 \mathrm{kDa}, \alpha$-casein and the fragment of $\gamma$-casein with a molecular weight of $\sim 23 \mathrm{kDa}$ are partially hydrolyzed (represented by low intensity and a diffuse zone) in LMPC-T-0.008-F and LMPC-T-0.008-F . In lane 9 and lane 10, the proteins and peptides present in LMPC$\mathrm{T}-0.016-\mathrm{F}$ and LMPC-T-0.016- $\mathrm{F}_{\mathrm{G}}$ are shown. It is notable that $\alpha$-casein and the fragment of $\gamma$-casein with a molecular weight of $\sim 23 \mathrm{kDa}$ are almost hydrolyzed in LMPC-T-0.016$\mathrm{F}$ and LMPC-T-0.016- $\mathrm{F}_{\mathrm{G}}$. In lane 12 and lane 13, the proteins and peptides, present in LMPC-T-0.032-F and LMPC-T-0.032- $\mathrm{F}_{\mathrm{G}}$, are shown. It can be seen that the protein conjugate with a molecular weight of $\sim 37 \mathrm{kDa}, \beta$-lactoglobulin and the fragment of $\gamma$-casein with a molecular weight if $16 \mathrm{kDa}$ are mostly hydrolyzed in LMPC-T-0.032-F and LMPC-T-0.032$\mathrm{F}_{\mathrm{G}}$. Hydrolysis of casein and whey proteins by Lactobacillus bulgaricus and Streptococcus thermophilus has been reported by several investigators [53,54]. In lane 14 and lane 15, proteins and peptides, as present in LMPC-F and LMPC-F $\mathrm{Gm}_{\text {, }}$ are shown. Here, the protein bands are similar to LMPC, as shown in lane 4 . In all cases, it was found that the addition of glucose has no effect on the microbial hydrolysis of proteins.

\subsection{Aquaphotomics Analysis}

The aim of this analysis is to understand the effect of the concentration of trypsin and microbial fermentation on the modulation of the hydrogen bond in compounds during 
the proteolysis of LMPC. In Figure 5A,B, aquagrams of tryptic hydrolysis of LMPC with three different concentrations of trypsin at the start time (immediately after the addition of trypsin) and after $10 \mathrm{~min}$ of incubation, respectively, are presented. In both cases, the aquagram of LMPC without trypsin is included to understand the change of the O-H bond during the tryptic hydrolysis reaction.

(A)

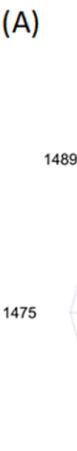

1463

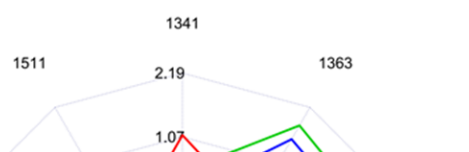

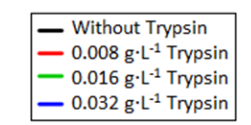

(B)

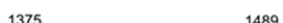

1375

$1384 \quad 1475$

1412

1427

1451

1439
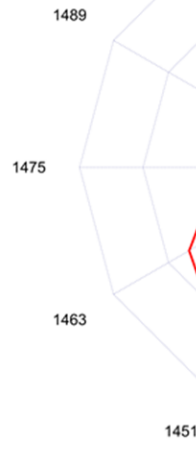

1451

1439
(B)

1463
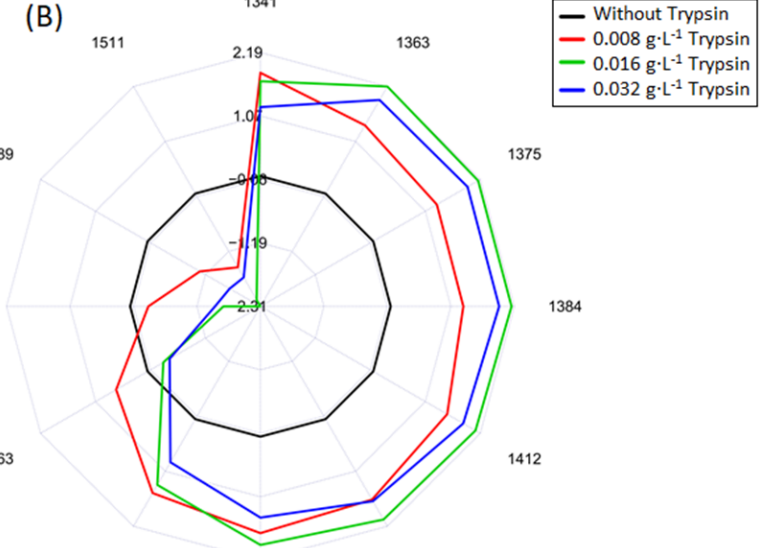

(C)<smiles>Cl[AsH2]=C=[AsH2]</smiles>

\section{E: Enzyme}

$S:$ Substrate

$T$ : Tetrahedral complex

$A$ : Acyl enzyme

$\mathrm{NH}_{2}-P_{1}$ : First product of enzymatic reaction

$\mathrm{P}_{2}$ - COO: Second product of enzymatic reaction

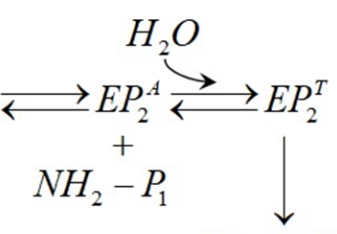

(D)

1427
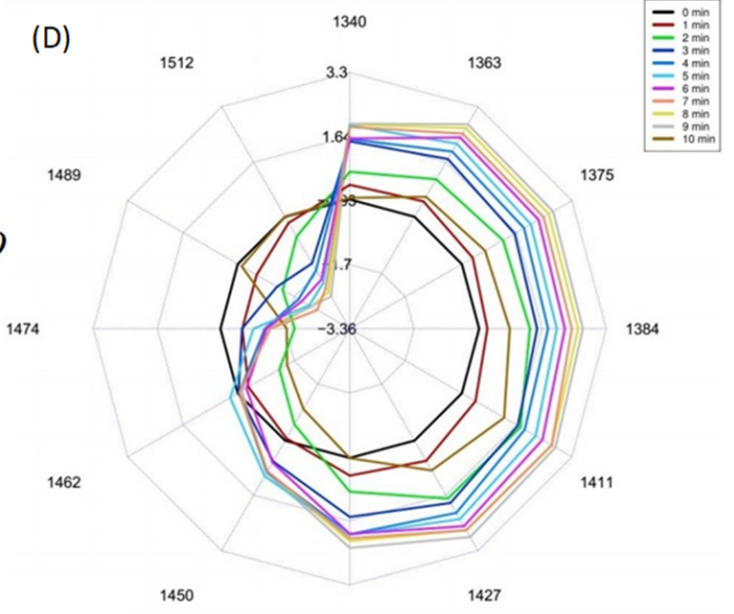

1384
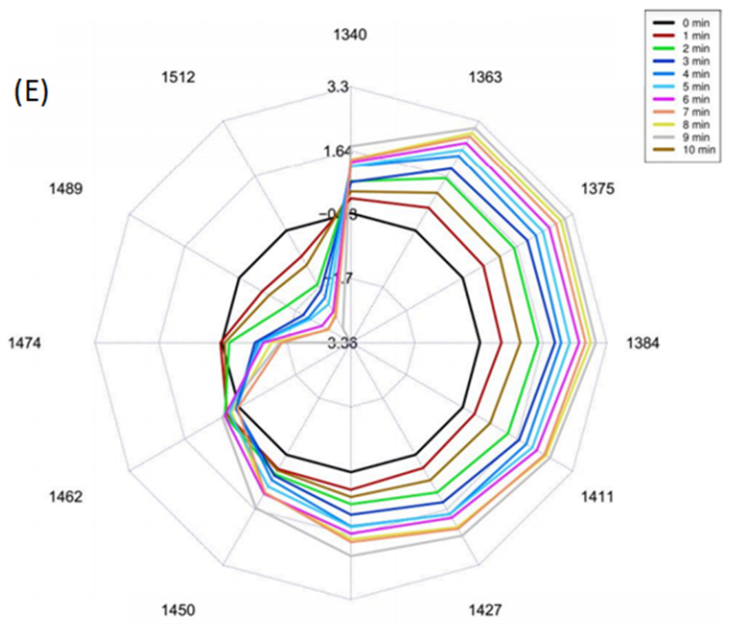

(F)

1439

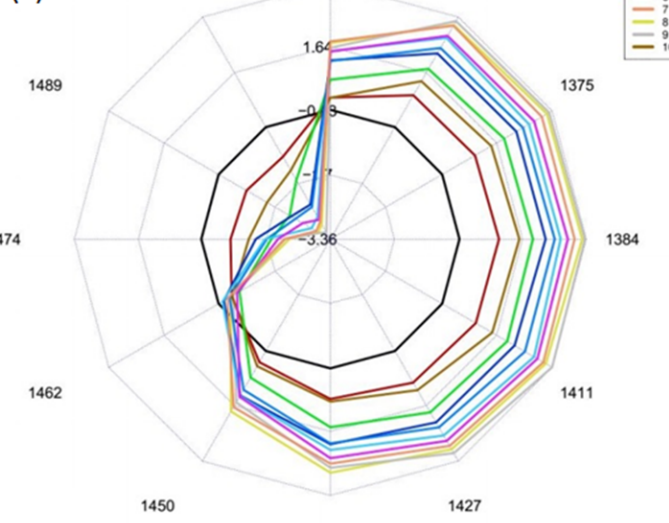

1450

1439

Figure 5. Aquagrams of the protein hydrolysis reaction with three different concentrations of trypsin at the start time (A) and after $10 \mathrm{~min}$ (B). Catalytic cycle of trypsin during protein hydrolysis (C). Aquagrams of the protein hydrolysis reaction by $0.008 \mathrm{~g} \cdot \mathrm{L}^{-1}$ of trypsin (D), $0.016 \mathrm{~g} \cdot \mathrm{L}^{-1}$ of trypsin $(\mathbf{E})$, and $0.032 \mathrm{~g} \cdot \mathrm{L}^{-1}$ of trypsin $(\mathbf{F})$. 
Without any doubt, it can be seen that with the increase of the concentration of trypsin from $0.008 \mathrm{~g} \cdot \mathrm{L}^{-1}$ to $0.016 \mathrm{~g} \cdot \mathrm{L}^{-1}$, the breakdown or presence of a weak hydrogen bond in the compound is significant (Figure $5 \mathrm{~A}$ ), and is further increased after $10 \mathrm{~min}$ of incubation (Figure 5B). This is represented by the increase of absorbance between the wavelengths of $1341 \mathrm{~nm}$ and $1451 \mathrm{~nm}$. This demonstrates the weaker hydrogen bonding structure in molecules and bulk water $[55,56]$. It is well known that in the hydrolysis of proteins (proteolysis reaction), the water dissociates along with the breaking of the peptide bond in the protein molecule. On the other hand, the decrease in absorption between the wavelengths of $1475 \mathrm{~nm}$ and $1511 \mathrm{~nm}$ represents the reduction in the strong hydrogen bond in the molecules $[55,56]$. However, no significant increase is observed when the proteolysis reaction is performed with $0.032 \mathrm{~g} \cdot \mathrm{L}^{-1}$ of trypsin, compared to $0.016 \mathrm{~g} \cdot \mathrm{L}^{-1}$ of trypsin.

In the catalytic triad of trypsin, three amino acids, such as Asp 102, His 57 and Ser 195, participate in the proteolysis reaction. The trypsin-catalyzed proteolysis reaction follows a ping-pong mechanism, which involves the formation of several intermediates. The first step of the trypsin-catalyzed proteolysis reaction is the formation of a Michaelis complex. A proton is transferred from the serine hydroxyl group to the $\mathrm{N}-\varepsilon_{2}$ of His-57. The hydroxyl group of Ser-195 (a nucleophile) twists around the $C_{\alpha}-C_{\beta}$ bond and interacts with the electrophilic carbon of the protein by covalent bonding. Subsequently, this converts into a short-lived tetrahedral intermediate. On the other side, positively charged His-57 become stabilized due to the transfer of a proton to the hydroxyl group of Asp-102. The tetrahedral intermediate is stabilized by the covalent bond and hydrogen bond. The negatively charged oxygen in the tetrahedral intermediate is stabilized by the hydrogen bond, developed with the nitrogen residues 195 and 193 in the substrate. Another hydrogen bond is created between the carboxylic group of Ser-214 and the $\alpha-N$ of the protein. In the tetrahedral structure, the unstable carbon-nitrogen bond breaks and a double bond between the $\mathrm{O}$ and the original carbonyl $\mathrm{C}$ is created. In this step, first, the product with the amino group freely diffuses away with a proton (acylation) from the protonated histidine, and the bound part of the substrate reorganizes to a covalently modified acyl-enzyme intermediate. Subsequently, the abovementioned mechanism repeats in the catalytic cycle, with water as a nucleophilic substance, which attacks the acyl-enzyme intermediate and forms a tetrahedral intermediate. As before, the intermediate collapses back and a second product with the carboxylic group moves to the solution (deacylation). This is considered as a rate-determining step. The carboxylic group loses a proton to the solution and becomes negatively charged. The residual part after the removal of a second product with the carboxylic group becomes reprotonated by the histidine and, consequently, the regenerations of both histidine and serine allow them to participate in another catalytic cycle $[57,58]$. This biochemical mechanism is elucidated in a simple way in Figure 5C. From the above discussion, it can be established that the presence of a hydrogen bond in the nucleophile and serin, and the formation of a tetrahedral enzyme-substrate intermediate with a hydrogen bond, have a great impact in the trypsin-catalyzed proteolysis reaction. The breaking of the hydrogen bond shifts the absorbance at wavelengths of $1341 \mathrm{~nm}, 1363 \mathrm{~nm}$, $1375 \mathrm{~nm}, 1384 \mathrm{~nm}$, and $1412 \mathrm{~nm}$ in a significant way. Our results may be explained by the fact that with an increase in the concentration of trypsin, from $0.008 \mathrm{~g} \cdot \mathrm{L}^{-1}$ to $0.016 \mathrm{~g} \cdot \mathrm{L}^{-1}$, the formation of the first product with the amino group and, consequently, of the second product with the carboxylic group are facilitated. At higher concentrations of trypsin, such as $0.032 \mathrm{~g} \cdot \mathrm{L}^{-1}$, more hydrogen bonds are created in the tetrahedral structures of enzymes and substrates, which may provide stability to the tetrahedral intermediate. As a result, the rate-limiting diacylation step in the proteolysis reaction is hindered. In Figure 5D-F, changes in the aquagrams according to the different concentrations of trypsin with the progression of the proteolysis time are represented. In all cases, the breakdown of the hydrogen bonds or the presence of weak hydrogen bonds with the passage of time is observed. This might be attributable to the breaking of the hydrogen bond between the tetrahedral enzyme-substrate intermediate and the nucleophilic water. 
In Figure 6A,C,E, aquagrams of the microbial hydrolysis of LMPC, treated with $0.008 \mathrm{~g} \cdot \mathrm{L}^{-1}, 0.016 \mathrm{~g} \cdot \mathrm{L}^{-1}$ and $0.032 \mathrm{~g} \cdot \mathrm{L}^{-1}$ of trypsin, are shown.
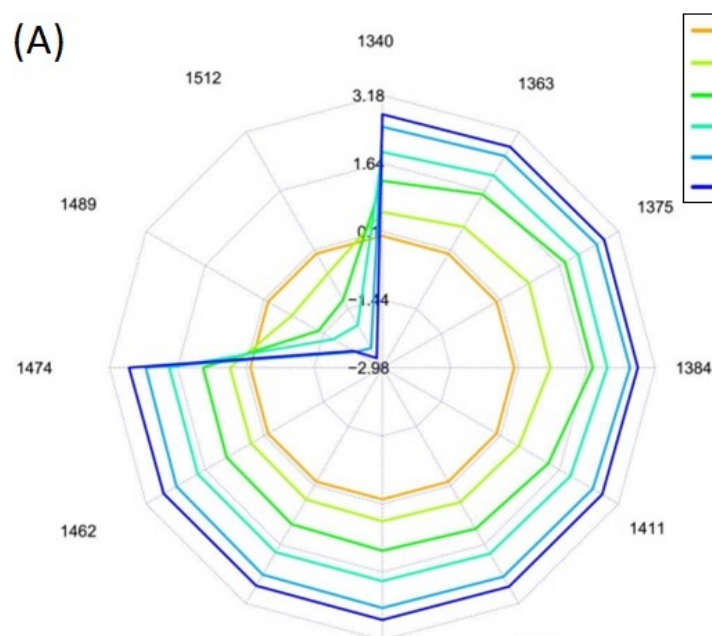

1450

(C)

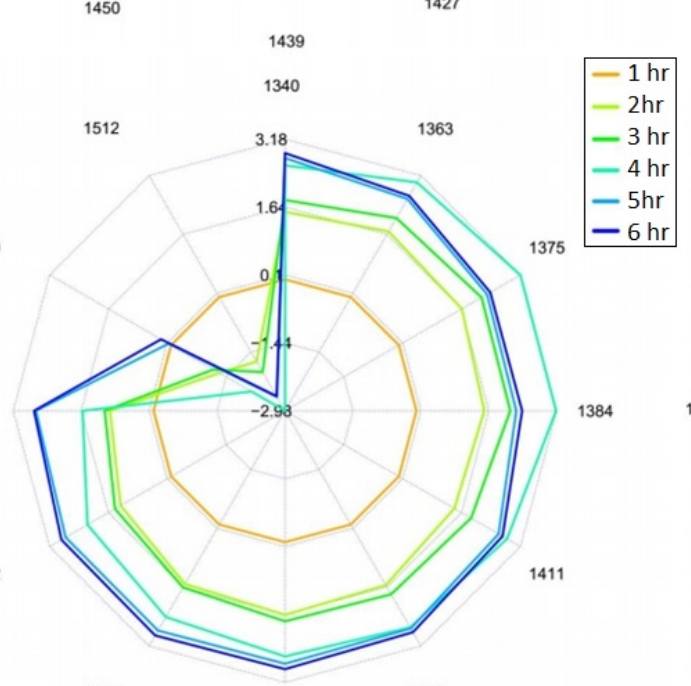

1427

(E)
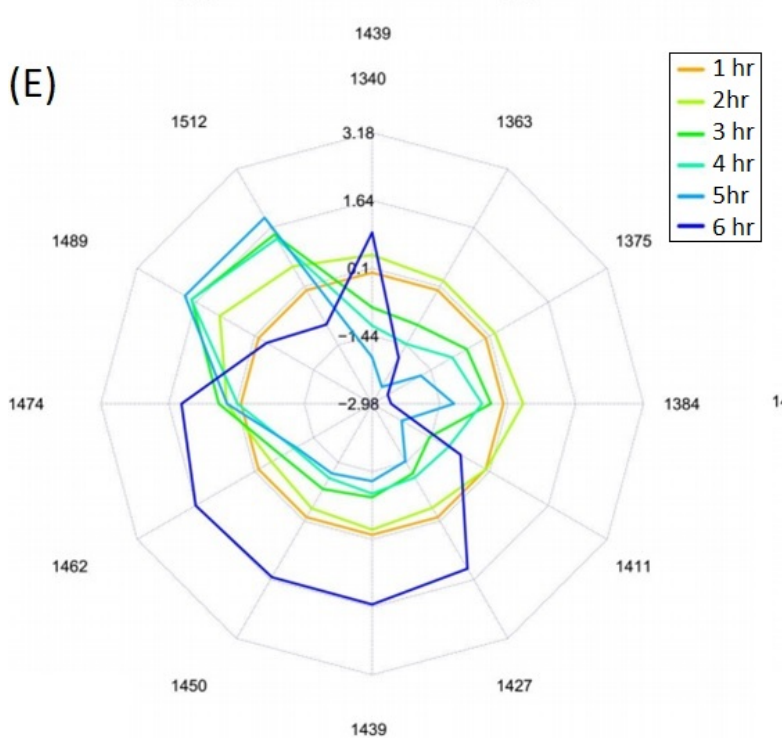

(B)

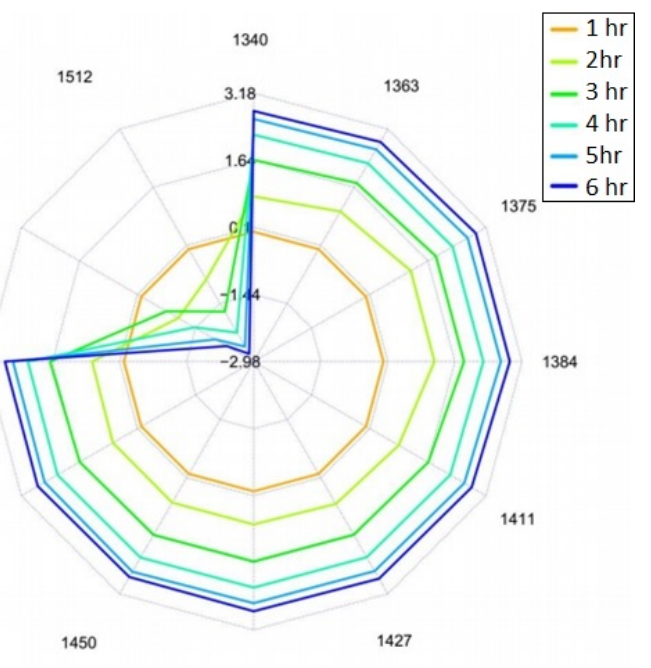

(D)
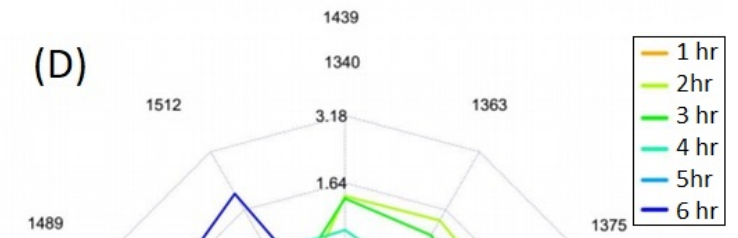

140

1474

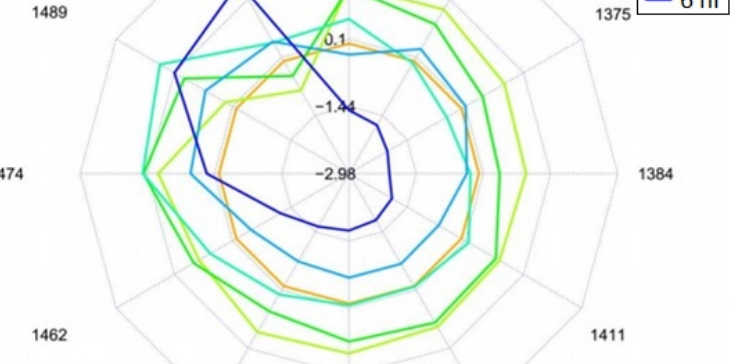

1489

1450

1427

(F)

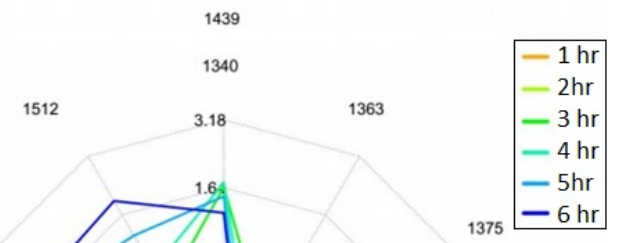

Figure 6. Aquagrams of the microbial hydrolysis of (A) LMPC-T-0.008, (B) LMPC-T-0.008 with glucose, (C) LMPC-T-0.016, (D) LMPC-T-0.016 with glucose, (E) LMPC-T-0.032, and (F) LMPC-T-0.032 with glucose. 
In Figure 6A, it is noted that the breakdown of the hydrogen bond or a weaker hydrogen bond in the compound progresses with the increase in fermentation time for LMPC-T-0.008-F. In Figure 6C, it can be observed that the breakdown of the hydrogen bond or a weaker hydrogen bond is seen after up to $5 \mathrm{~h}$ of fermentation and, subsequently, biomolecules with a hydrogen bond are formed. According to Figure $6 \mathrm{E}$, the breakdown of the hydrogen bond or a weaker hydrogen bond is shown after up to $2 \mathrm{~h}$ of fermentation, and in the subsequent time period, biomolecules with more hydrogen bonds are formed. Muncan and co-authors reported that the entire wavelength region of 1300-1400 nm has significant importance during the aquaphotomics analysis of the fermentation of milk with lactic acid bacteria. According to these authors, this region corresponds to the absorbance of weakly or non-hydrogen-bonded water, indicating the existence of a protein concentrate in liquid phase, in other words, non-coagulated protein [59]. The hydrolysis of proteins by trypsin, prior to fermentation, facilitates the breakdown of exogenous proteins into lower molecular-weight oligopeptides, which increases the solubility of proteins and reduces the coagulation of proteins [60]. This is clearly visible in Figure 6A,C,E. Furthermore, it has been reported that the absorbance at a wavelength of $1361 \mathrm{~nm}$ can represent the proton hydrated/solvated hydronium ion $[61,62]$ and/or water hydration shells [55] with a very weak hydrogen bond. This can be attributed to the formation of organic acids, including lactic acid, with a low dissociation constant during lactic acid bacteria fermentation. According to Broyard and Gaucheron, the destruction of casein micelles is induced by acidification. The concentration and types of organic acids, including lactic acid, have a key role in the destruction of casein micelles. Due to the acidification, the inorganic mineral phosphate within the casein micelle is solubilized, and the casein micelle is destroyed. Furthermore, a wavelength of $1361 \mathrm{~nm}$ reflects the change in microbial growth [63]. It is noted that the development of biomolecules with a strong hydrogen bond in the fermentation process increased with the increase in the concentration of trypsin, used for the hydrolysis of LMPC before fermentation. This is represented by the increase of absorbance between the wavelengths of $1450 \mathrm{~nm}$ and $1512 \mathrm{~nm}$. Lactic acid bacteria are not able to uptake exogenous proteins. They hydrolyze exogenous proteins or large molecular-weight peptides to oligopeptides by cell-wall proteinases (PrtP). However, cellwall proteinases of lactic acid bacteria have different specificities; at least two types of cell-wall proteinases in the family of serine proteinases have been identified. The PI-type cell-wall proteinases hydrolyze $\beta$-casein and, to some extent, $\alpha_{\mathrm{s} 1}$-casein. The PIII-type cellwall proteinases hydrolyze both caseins [64]. Furthermore, the hydrolysis of $\alpha$-lactalbumin and $\beta$-lactoglobulin, by cell-wall proteinase Streptococcus thermophilus and Lactobacillus bulgaricus, have been well documented [65]. Subsequently, oligopeptides are transformed to the biotic phase of lactic acid bacteria by transporter membrane proteins, such as Opp, DtpP and DtpT. Oligopeptides are converted to nitrogenous metabolites, such as amino acids, aroma (amines and sulfur compounds), and organic acids through different metabolic pathways [64]. The metabolic pathway of lactic acid bacteria during the fermentation of concentrated milk is represented in Figure 7.

Therefore, the hydrolysis of exogenous proteins by trypsin, prior to fermentation, facilitates the transportation of peptides to the intracellular phase by cell-wall transporter proteins and their bioconversion to amino acids, amines, sulfur compounds and lactic acid $[64,66]$. Lactobacillus bulgaricus and Streptococcus thermophilus are homofermentative lactic acid bacteria. During the microbial fermentation of milk protein and lactose, lactic acid is primarily produced. The lactic acid becomes protonated and the $\mathrm{pH}$ of the medium is reduced [67]. Nucleophilic species lactate (negative charge on the oxygen atom of the carboxylic group) may bind with the electrophilic sites of proteins or peptides with a hydrogen bond $[68,69]$. Peptides, shorter than five amino acid residues, are usually soluble in an aqueous medium, except when the entire sequence consists of hydrophobic amino acids (tryptophan, leucine, isoleucine, phenylalanine, methionine, valine, and tyrosine). Hydrophilic peptides, containing $>25 \%$ charged residues (aspartic acid, lysine, arginine, histidine and glutamic acid) and $25 \%$ hydrophobic amino acids, are usually soluble in an 
aqueous medium. The presence of other hydrophilic amino acids (asparagine, glutamine, serine, threonine, hydroxy-proline and pyroglutamic acid) are also responsible for the solubility of peptides [70]. The hydrolytic product of protein, i.e., peptides, are soluble in an aqueous medium when the electrostatic repulsion among them is greater than the hydrophobic interaction [71]. Peptides and enzyme-hydrolyzed proteins have better solubility than native proteins. Treatment of the enzyme reduces the molecular weights of proteins or peptides, triggers hydrophobic interactions within protein molecules, and unfolds the tertiary or quaternary structures of proteins [72,73]. In the peptide chain, polar amino acids can form hydrogen bonds with water molecules. Often, Lactobacillus bulgaricus and Streptococcus thermophilus produce exopolysaccharides from lactose, besides the formation of lactic acid [74,75]. The polar part of the exopolysaccharide, such as ethyl-, methyl- and hydroxyl- groups, can bind with proteins or peptides or water via hydrogen bonds [69].

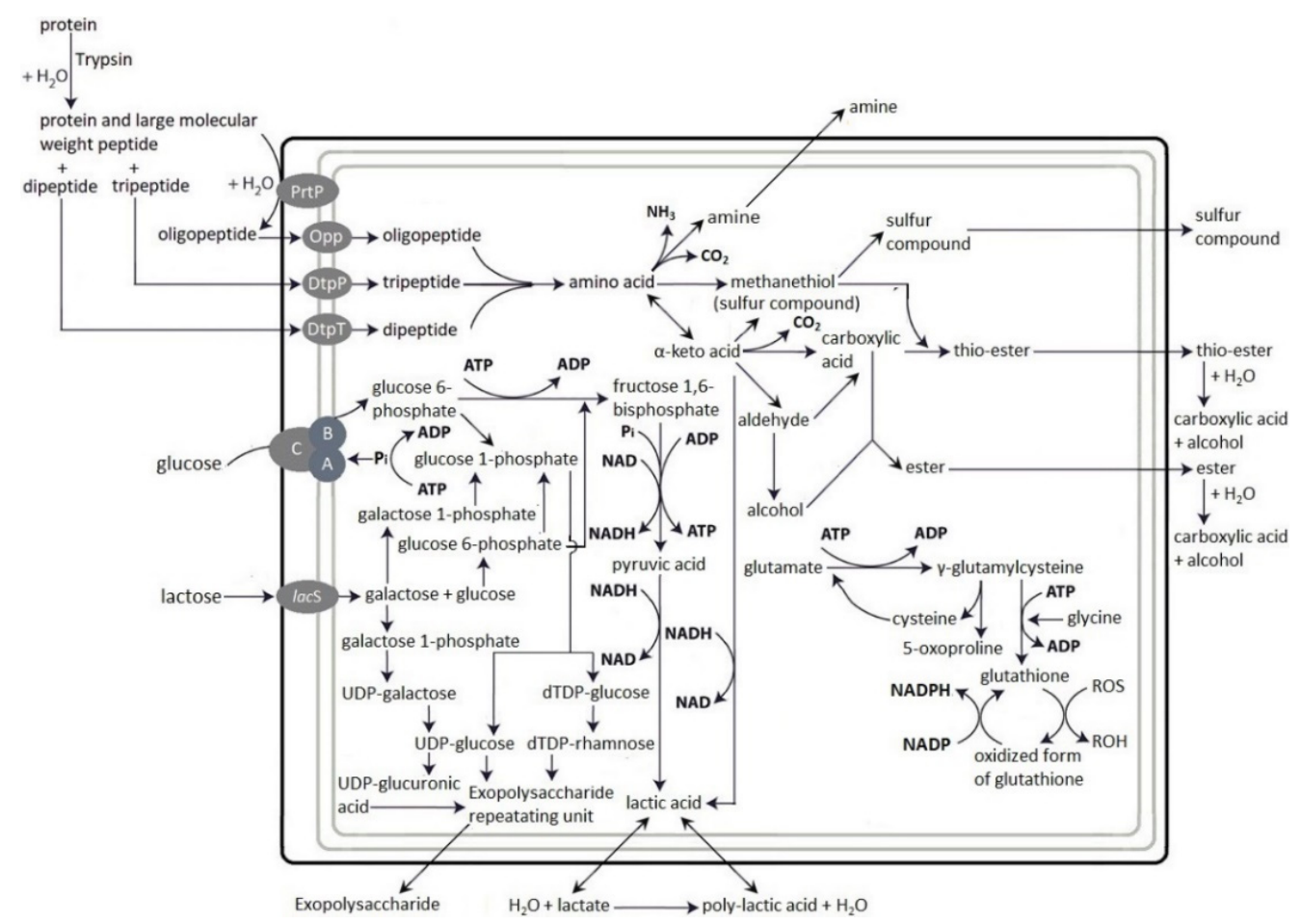

Figure 7. Metabolic pathway of lactic acid bacteria during the fermentation of concentrated milk (graphic self-developed; concept was adopted from Savijoki et al., 2006 [64] and Zhang et al., 2020 [66]).

Aquagrams for the microbial fermentation of LMPC-T-0.008, LMPC-T-0.016, and LMPC-T-0.032 with glucose are represented in Figure 6B,D,F, respectively. Comparing the aquagrams represented in Figure 6A,B, there is no significant difference. According to Figure $6 \mathrm{D}, \mathrm{F}$, the breaking of the hydrogen bond or the presence of a weaker hydrogen bond is revealed after up to $2 \mathrm{~h}$ of fermentation, and in the subsequent time period, biomolecules with more hydrogen bonds are produced. It is notable that the formation of biomolecules with a hydrogen bond is more common in LMPC-T-0.032- $\mathrm{F}_{\mathrm{G}}$ than LMPC$\mathrm{T}-0.016-\mathrm{F}_{\mathrm{G}}$. The addition of glucose may enhance the microbial growth and formation of microbial metabolites, such as nitrogenous compounds, exopolysaccharides and lactate [76]. According to Figure 6E,F, more hydrophilic compounds or water-bounded compounds are produced in LMPC-T-0.032- $\mathrm{F}_{\mathrm{G}}$ than LMPC-T-0.032-F. Due to the addition of glucose in LMPC-T, more specifically LMPC-T-0.016 and LMPC-T-0.032, a high concentration of lactic acid is assumed to be produced in the fermentation broth and, subsequently, this may be converted into polylactic acid by hydrogen bonding [77]. Muncan and co-authors reported the importance of a wavelength of $\sim 1428 \mathrm{~nm}$ during milk fermentation with lactic acid bacteria. It has been reported that the wavelength of $\sim 1428 \mathrm{~nm}$ may be the 
cause of the intermediate water structure. A wavelength of $\sim 1428 \mathrm{~nm}$ may represent the hydration of water and water hydrating proteins [68]. Alternatively, it has been reported that the wavelength of $\sim 1428 \mathrm{~nm}$ may be related to the glucose molecule, the basic structure of complex polysaccharides [78], which indicates a possible interaction between exopolysaccharides and water. In both cases, the weak hydrogen bond plays a role. In Figure $6 \mathrm{~B}, \mathrm{D}, \mathrm{F}$, the increase of the wavelength of $\sim 1428 \mathrm{~nm}$ is visible. This represents the formation of the hydrating peptides, produced by the hydrolysis of milk proteins and oligopeptides by microorganisms. Furthermore, this is attributed to the contribution of glucose to the synthesis of exopolysaccharides during fermentation.

\subsection{Antioxidant Capacity}

The antioxidant capacity of LMPC is $167.35 \pm 9.8 \mathrm{mg}$, equivalent to ascorbic acid $\cdot \mathrm{L}^{-1}$ and $20.94 \pm 1.49 \%$, according to the FRAP assay and DPPH radical scavenging activity assay, respectively (Figure 8A). It is shown that antioxidant capacity, measured by the FRAP assay and DPPH radical scavenging assay, is increased due to the tryptic hydrolysis of LMPC.

(B)

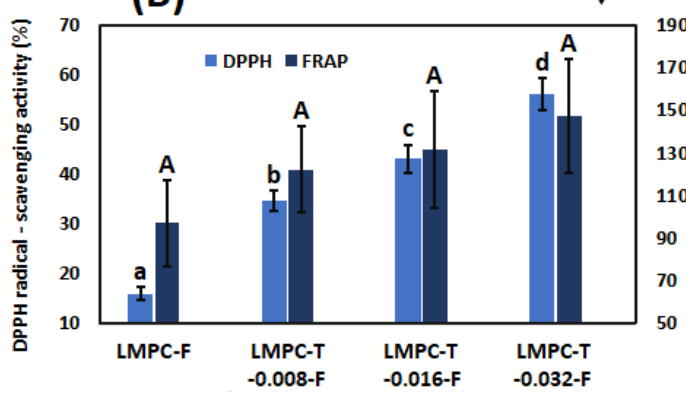

(A)

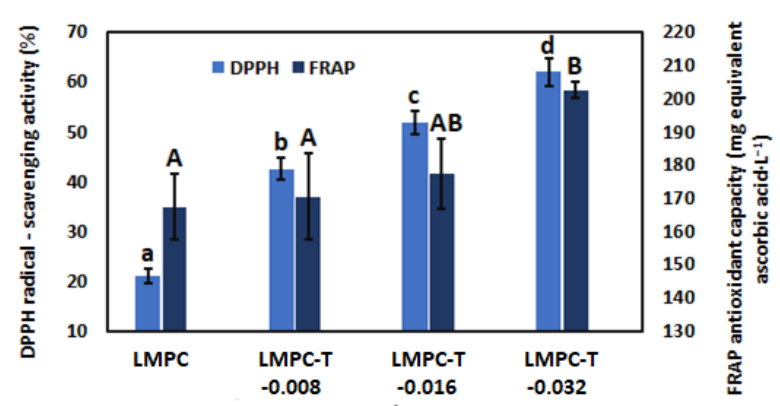

Figure 8. The antioxidant capacity of LMPC and LMPC-T (A), LMPC-F and LMPC-T-F $(\mathbf{B})$ and LMPC- $\mathrm{F}_{\mathrm{G}}$ and LMPC-T-F $\mathrm{G}$ (C). Results are represented with a mean value and standard deviation ( \pm values) of three triplicate experimental results. In superscript, the dissimilar alphabet represents significant differences between the results.

In the protein structure, trypsin cleaves the peptide bond between the carboxyl group of basic amino acid lysine or arginine in the C-terminus position and the amino group of the adjacent amino acid in the hydrophobic side chain in the N-terminal position, when there is no proline. The presence of hydrophobic amino acids (alanine, isoleucine, leucine, methionine, phenylalanine, valine and glycine) and amino acids with imidazole moiety, such as histidine in peptide, is due to the tryptic hydrolysis of LMPC reducing the $\mathrm{Fe}^{3+}$ TPTZ complex. It has been reported that peptides with a lower molecular weight exhibit better reducing activity toward $\mathrm{Fe}^{3+}$. Smaller peptides have a higher charge-to-mass ratio than larger peptides, because of the exposure of more electron-rich side chains. Similarly, peptides produced by the tryptic hydrolysis of milk proteins, act as electron donors and can convert DPPH free radicals into a more stable molecule. The hydrophobic amino acid at the $\mathrm{N}$-terminus position of peptide offers radical scavenging activity [79]. Therefore, peptides with lower molecular weight and a higher charge density (charge-to-mass ratio) offer better 
scavenging activity and reacting with free radicals, due to low steric hindrance $[79,80]$. Similar findings have been reported by other investigators. In one investigation, bovine sodium caseinate solution $\left(10 \mathrm{~g}\right.$ protein $\left.\cdot \mathrm{L}^{-1}\right)$ was hydrolyzed with trypsin. Four different ratios of enzyme and substrate, such as 1:25, 1:50, 1:100 and 1:200 (w/w), pH 7 and temperature $37^{\circ} \mathrm{C}$ for $15 \mathrm{~min}, 30 \mathrm{~min}, 60 \mathrm{~min}$ and $120 \mathrm{~min}$, had been considered in the experiment. The antioxidant capacity, measured by DPPH-radical scavenging assay and FRAP assay increased along with an increase in the concentration of enzymes [80]. In another investigation, cow's milk was hydrolyzed with different concentrations of trypsin, such as $0.001 \%, 0.005 \%$ and $0.01 \%(w / w)$ at $\mathrm{pH} 7$, and a temperature of $37^{\circ} \mathrm{C}$ for $30 \mathrm{~min}$ and subsequently heating at a temperature of $100{ }^{\circ} \mathrm{C}$ for $10 \mathrm{~min}$. DPPH-radical scavenging activities were $61.27 \pm 1.38,62.94 \pm 1.42$ and $64.99 \pm 1.29$, when concentrations of trypsin were $0.001 \%, 0.005 \%$ and $0.01 \%$, respectively [81].

The antioxidant capacity of LMPC-T-F and LMPC-T-F $\mathrm{F}_{\mathrm{G}}$ are shown in Figure 8B,C, respectively. According to the FRAP assay, the antioxidant capacity of LMPC-F and LMPC$\mathrm{F}_{\mathrm{G}}$ was $97.05 \pm 20.48 \mathrm{mg}$ equivalent ascorbic acid $\cdot \mathrm{L}^{-1}$ and $78.72 \pm 10.12 \mathrm{mg}$ equivalent ascorbic acid $\cdot \mathrm{L}^{-1}$, respectively. According to the DPPH assay, the radical scavenging activities of LMPC-F and LMPC-F $F_{G}$ were $15.97 \pm 1.38 \%$ and $14.00 \pm 1.19 \%$, respectively. According to Figure 8B, the antioxidant capacity of the fermentation broth increased with an increase in the concentration of trypsin, applied prior to fermentation. It has already been mentioned that peptides with a lower molecular weight and higher charge density (charge-to-mass ratio) have better antioxidant potency $[79,80]$. Sabeena Farvin and co-authors reported that higher radical scavenging activity in the water-soluble protein fraction of yogurt contains peptides with a molecular weight of 3-10 kDa and $<3 \mathrm{kDa}$, which donate electrons to the free radicals to produce stable compounds. Radical scavenging activity was low in the water-soluble protein fraction of yogurt with a higher molecular weight (> $30 \mathrm{kDa}$ and 10-30 kDa) of peptides [82]. Furthermore, it has been reported that peptides in fermented milk containing hydrophobic amino acid residues, such as Val or Leu at the N-terminus; Pro, His or Tyr among amino acid sequences have an antioxidant capacity [83]. The antioxidant capacity of LMPC-T-F and LMPC-T-F might be related to various factors, such as (a) the biochemical characteristics of milk, (b) the type/amount of starter culture, (c) fermentation technology, (d) the activity of the starter culture, and (e) the method for determining antioxidant capacity [84]. It has been reported that peptides with an antioxidant capacity are produced during the fermentation of milk by Lactobacillus bulgaricus and Streptococcus thermophilus [85]. Since lactic acid bacteria cannot directly uptake exogenous proteins, they hydrolyze exogenous proteins or oligopeptides by cell-wall proteases to enable their transportation to the biotic phase. Peptides with an antioxidant capacity are produced by the proteolytic activity of the cell-wall and intracellular proteolytic systems of lactic acid bacteria [64,66]. Lactobacillus bulgaricus releases hydrophilic and hydrophobic peptides from $\beta$-lactoglobulin, whereas Streptococcus thermophilus releases only hydrophilic peptides from $\beta$-lactoglobulin [65]. Furthermore, it has been reported that hydrophobic peptides are produced from caseins by Lactobacillus bulgaricus and Streptococcus thermophilus $[54,86,87]$. These hydrophobic peptides give the antioxidant capacity. Therefore, the hydrolysis of proteins by trypsin prior to fermentation facilitates the breakdown of larger proteins, to yield peptides small enough to be transferred into the bacterial cell. Furthermore, it is shown that the antioxidant capacity of LMPC-T-F and LMPC-T$\mathrm{F}_{\mathrm{G}}$, measured by DPPH and FRAP assays, is lower than in LMPC-T. In the intracellular environment, milk protein-derived antioxidative peptides are converted to cysteine by aminopeptidases and endopeptidases [88] and, subsequently, cysteine is converted to glutathione (intracellular antioxidant) in the presence of $\gamma$-glutamylcysteine synthetase. Glutathione, as well as the glutathione redox cycle, protect the microbial cell from oxidative stress and increase the survival rate of microorganisms in the fermentation process $[89,90]$. The bioconversion of low molecular-weight peptides, produced by the cell-wall proteinases, to diverse metabolites, such as amino acids, amines, sulfur compounds and lactic acid, occurs through different metabolic pathways in the biotic phase of the higher population 
of lactic acid bacteria. Therefore, the yield of peptides with an antioxidant capacity in the fermentation broth is reduced. Similar results have been published by Yilmaz-Ersan and co-authors. They reported that the antioxidant capacity in kefir from cow's milk, measured by DPPH assay and FRAP assay, has been reduced after $8 \mathrm{~h}$ of fermentation from commencing the test [84]. Although antioxidant capacity is somewhat reduced by the addition of glucose during the fermentation process, this change is not significant. This can be explained by the fact that the addition of glucose in the fermentation medium induces microbial growth [91,92], which promotes the breakdown of exogenous proteins and their bioconversion into lactic acid and nitrogenous metabolites $[64,66]$.

\subsection{Angiotensin-Converting Enzyme Inhibitory Activity}

Milk proteins are a rich source of peptides with angiotensin-converting enzyme inhibitory activity. In the case of LMPC, the inhibition of the angiotensin-converting enzyme was $\sim 6 \%$ at a maximal concentration of the protein $1.5 \mathrm{mg} \cdot \mathrm{mL}^{-1}$. Note that determination of the $\mathrm{IC}_{50}$ value of LMPC was not feasible, because of elevated autofluorescence (interfering with the fluorescent product of the angiotensin-converting enzyme reaction) in the presence of a higher concentration of protein in LMPC. The negligible angiotensin-converting enzyme inhibitory activity of LMPC may be explained by the poor interaction between natural milk proteins and the active angiotensin-converting enzyme, due to the presence of steric hindrance [93]. Similar results have been published by other researchers [94,95]. Therefore, angiotensin-converting enzyme inhibitory potency, represented by $\mathrm{IC}_{50}$ values for LMPC-T, is represented in Figure 9A.
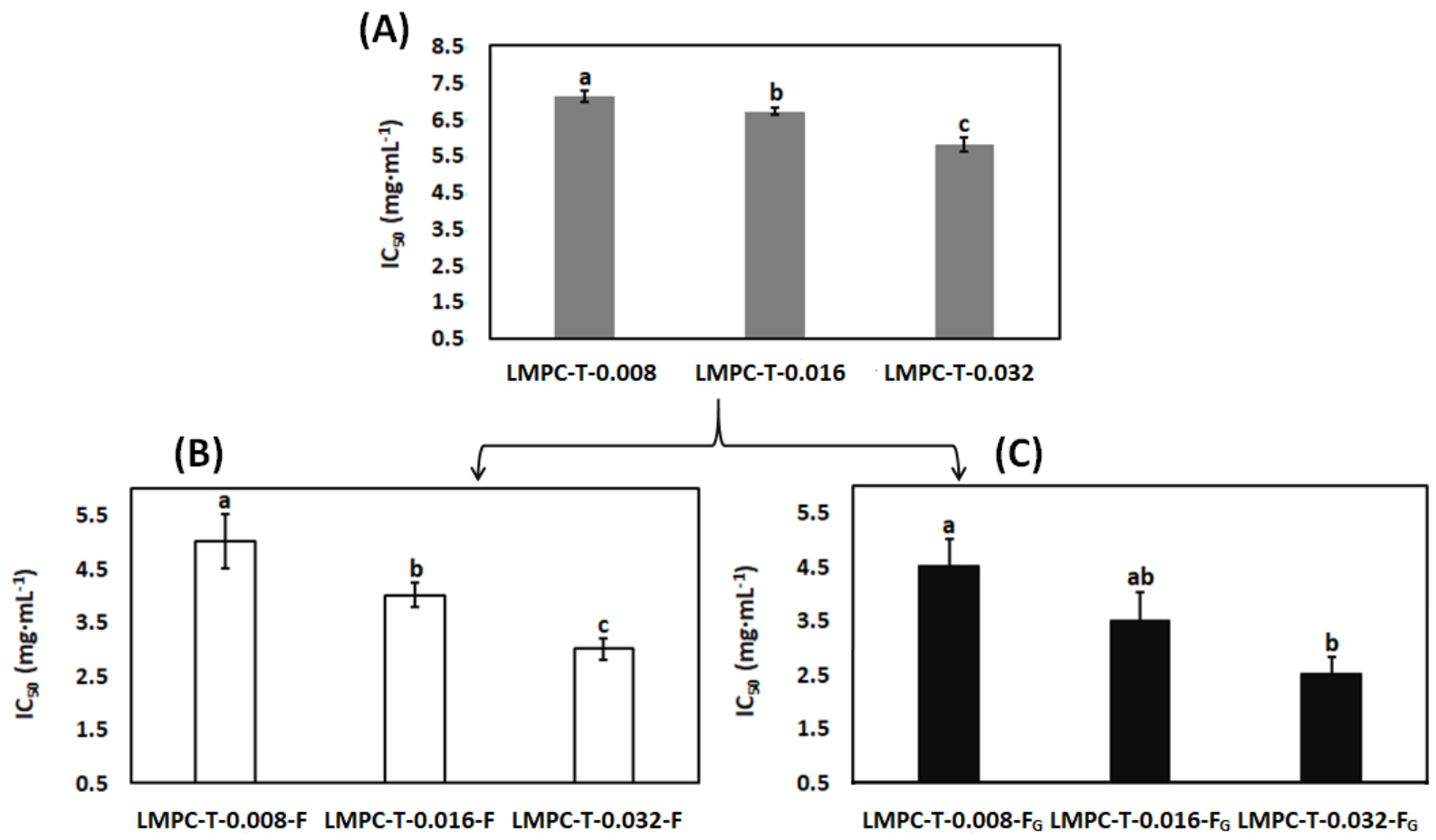

Figure 9. The value of $\mathrm{IC}_{50}$ of LMPC-T (A), LMPC-T-F (B) and LMPC-T-F $(\mathbf{C})$. Results are represented with a mean value and standard deviation ( \pm values) of three triplicate experimental results. In superscript, the dissimilar alphabet represents a significant difference between results.

It is noted that the $\mathrm{IC}_{50}$ value is significantly decreased after trypsin treatment in a concentration-dependent manner. Other researchers have also published similar findings $[96,97]$. The treatment of trypsin may unfold the natural milk protein and binding sites in a protein where the angiotensin-converting enzyme is exposed. Furthermore, the low molecular weight of peptides as produced by the tryptic hydrolysis of milk proteins has more chance to interact with the angiotensin-converting enzyme, due to less steric hin- 
drance [98]. Peptides with hydrophobic amino acids, such as phenylalanine, proline, tryptophan and tyrosine at the C-terminal position, can bind with the angiotensin-converting enzyme, and inhibitory activity is facilitated $[88,99]$. Furthermore, the presence of the positively charged amino acid lysine ( $\varepsilon$-amino group) and arginine (guanidino group) at the $\mathrm{C}$-terminal position can also contribute to the angiotensin-converting enzyme inhibitory activity [88]. IC 50 values of LMPC-T-F and LMPC-T- $F_{G}$ are represented in Figure 9B,C, respectively. It is noteworthy that the $\mathrm{IC}_{50}$ value is decreased in fermentation broth with an increase in the concentration of trypsin. It has been reported elsewhere that the hydrolysis of milk protein, especially casein, using the proteolytic system of lactic acid bacteria releases angiotensin-converting enzyme-inhibitory peptides $[100,101]$. Furthermore, it is noted that the $\mathrm{IC}_{50}$ values in LMPC-T-F $\mathrm{F}_{\mathrm{G}}$ are lower than LMPC-T-F. Similar results have been reported by other researchers. The fermentation of low-fat milk in the presence of inulin [102] and exopolysaccharide $[91,92]$ with lactic acid bacteria offers a lower IC $_{50}$ value compared to fermentation without the abovementioned carbohydrates. This can be explained by the fact that the addition of glucose in the fermentation medium promoted microbial growth, which influenced the proteolysis of milk proteins [91]. It is necessary to mention that we tested the medical angiotensin-converting enzyme inhibitor captopril in the assays as a positive control. The $\mathrm{IC}_{50}$ value of captopril has been determined as being $5 \mathrm{nM}$, similar to the previously reported results [103]. Its efficacy was $100 \%$, in accordance with human angiotensin-converting enzyme inhibition. These experiments suggested that our recombinant angiotensin-converting enzyme has similar properties to the angiotensin-converting enzyme found in human blood. Moreover, the full inhibition of the recombinant enzyme, both in the absence and in the presence of LMPC, LMPC-T-F and LMPC-T-F $\mathrm{F}_{\mathrm{G}}$, suggested that the biochemical assay is specific to the angiotensin-converting enzyme.

In Figure 10A, the activity of the angiotensin-converting enzyme in the presence of the different concentrations of protein in LMPC-T is shown. This demonstrates a non-competitive mechanism of angiotensin-converting enzyme inhibition by LMPC. This is similar to the endogenous angiotensin-converting enzyme inhibition in the human sera [38], as provided by serum albumin [103]. The $K_{m}$ value of LMPC-T is determined to be 77 micromolar.

(A)

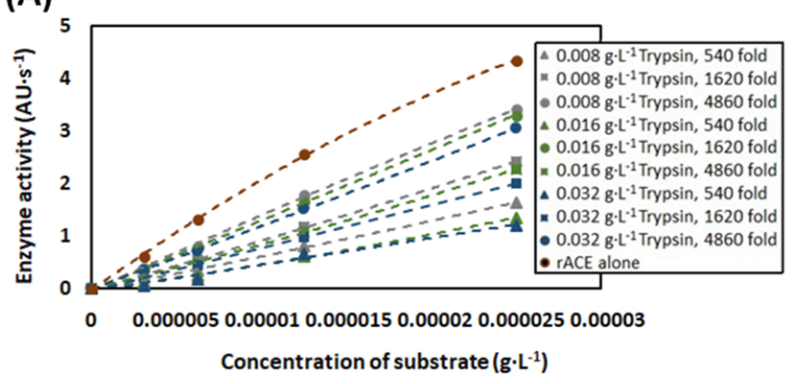

(C)

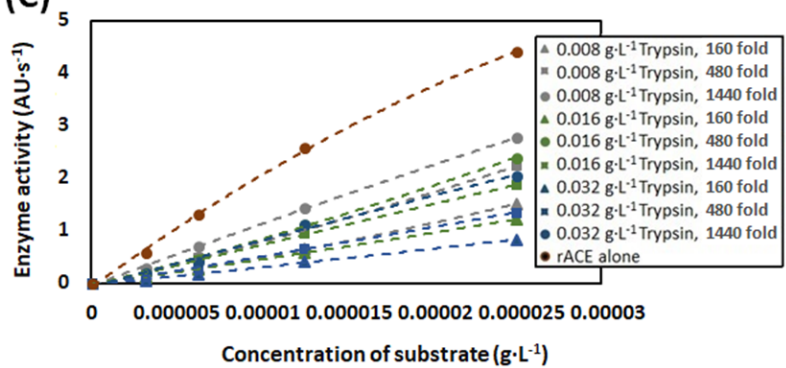

(B)

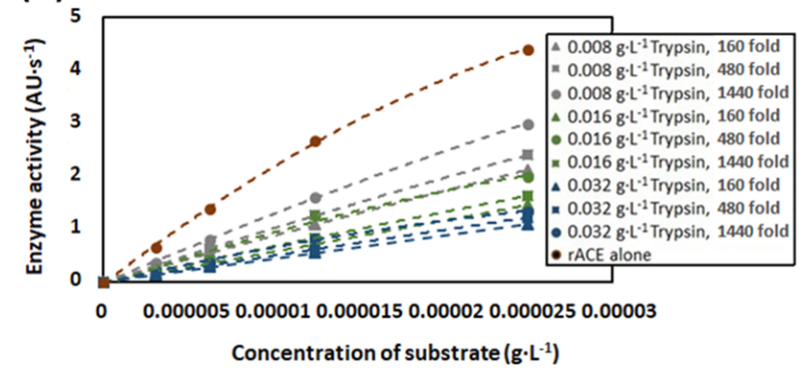

(D)

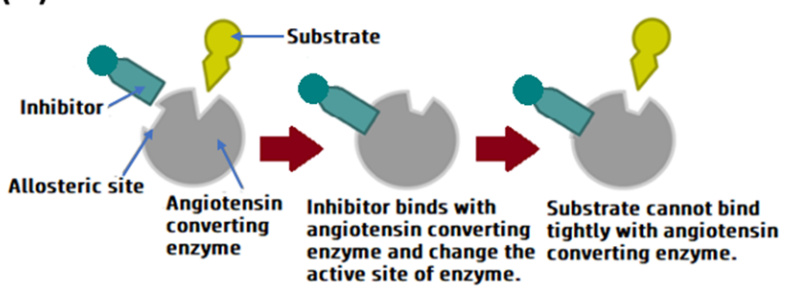

Figure 10. Activity of the angiotensin-converting enzyme in the presence of different concentrations of protein hydrolysate, prepared by the tryptic hydrolysis of LMPC (A), LMPC-T-F and (B) and LMPC-T-F $(\mathbf{C})$. Mechanism of the inhibition of the angiotensin-converting enzyme (D) (self-developed graphic; the concept was adopted from Guang and Phillips, 2009 [104] and Vallabha and Kaultiku, 2006 [105]). 
In Figure 10B,C, the activity of the angiotensin-converting enzyme in the presence of different concentrations of proteins in LMPC-T-F and LMPC-T- $\mathrm{F}_{\mathrm{G}}$, respectively, is represented. The results show a non-competitive mechanism of angiotensin-converting enzyme inhibition in both cases. The $K_{m}$ values of LMPC-T-F and LMPC-T- $\mathrm{F}_{\mathrm{G}}$ are determined to be 60 micromolar and 85 micromolar, respectively. Angiotensin-converting enzyme inhibitory peptides, produced in LMPC-T, LMPC-T-F and LMPC-T- $\mathrm{F}_{\mathrm{G}}$, may change the conformation of the active site of the angiotensin-converting enzyme, resulting in lower enzymatic activity (Figure 10D) [106].

\subsection{Antibacterial Activity}

When LMPC was tested, a zone of inhibition in an agar plate of test microorganisms was not found; however, some investigators reported that native whey proteins offer antibacterial activity [107]. Antibacterial activity in two isolated whey proteins, lactoferrin $[108,109]$ and lactoperoxidase $[110,111]$, has also been reported by some investigators. Our results may be explained by the fact that lower concentrations of the mentioned proteins are not able to offer antibacterial activity, represented by a zone of inhibition. A zone of inhibition has been found with LMPC-T for Bacillus cereus and Staphylococcus aureus. A zone of inhibition was not found when LMPC-T was tested for Listeria monocytogenes. It has been demonstrated that Gram-positive microbes are more sensitive to peptides, derived from whey proteins, compared to Gram-negative microbes [36]. It is noted that the zone of inhibition is significantly increased with an increase in the concentration of trypsin for the hydrolysis of LMPC (Figure 11A).

(A)

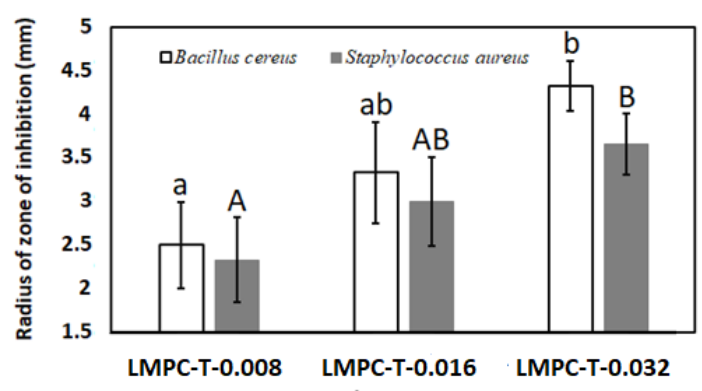

(B)
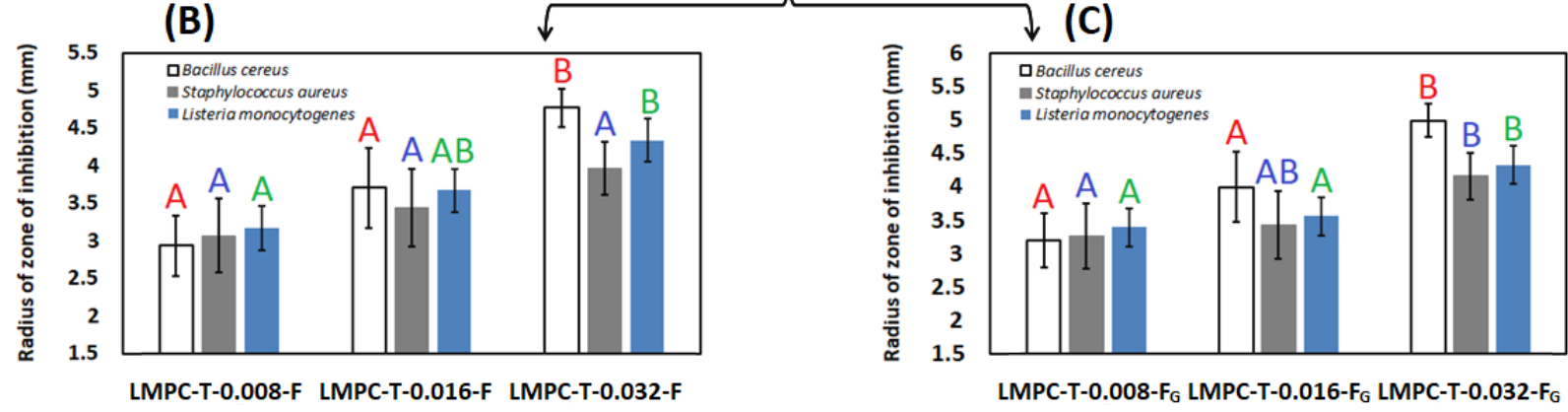

Figure 11. The zone of inhibition in mm (antibacterial activity), provided by LMPC-T (A), LMPC-T-F (B) and LMPC-T-F (C). Results are represented with a mean value and standard deviation ( \pm values) of three triplicate experimental results. In superscript, a dissimilar alphabet represents a significant difference between results.

There are several biochemical phenomena that can be addressed to explain the antibacterial activity of LMPC-T. Peptides with lysine and arginine (hydrophilic basic amino acids) in the C-terminus, and other hydrophilic, hydrophobic and amphiphilic amino acids in the $\mathrm{N}$-terminus, can bind with anionic lipoteichoic acid and teichoic acid in the peptidoglycan of the bacterial cell-wall, by electrostatic bonding. Subsequently, the peptide penetrates to the cytoplasmic membrane of bacteria and leads to lipid segregation in the cell membrane, the disarrangement of peripheral membrane proteins, and membrane permeability, which inhibits cell division. On the other hand, it has been reported that antibacterial peptides 
form a complex with the precursor molecules of cell-wall components, which might promote pore formation in the cell wall of microorganisms. Stable pores in the microbial cell membrane facilitate the permeabilization of intracellular cellular components into the cytosol, which causes cellular death [112]. It has been reported that the interaction between peptides and the bacterial cell membrane depends on (a) the amino acid sequence in the peptide, (b) the concentration of peptide, (c) the chemical composition of the bacterial cell membrane, and (d) the binding ability of peptides with the bacterial cell membrane [113]. The tryptic digestion of $k$-casein [114], whey proteins [107], $\alpha$-lactalbumin [115], and $\beta$-lactoglobulin [116] has shown antibacterial activity against Staphylococcus aureus. Furthermore, it has been reported that Casocidin-I, produced by the tryptic hydrolysis of $\alpha_{\mathrm{s} 2}$-casein, shows antibacterial activity against Staphylococcus carnosus [117].

However, LMPC has no antibacterial activity; antibacterial activity against all microbes, such as Bacillus cereus, Staphylococcus aureus and Listeria monocytogenes, is offered by LMPC-F, LMPC-F $\mathrm{G}_{\mathrm{G}}$, LMPC-T-F and LMPC-T- $\mathrm{F}_{\mathrm{G}}$. The values of the zones of inhibition are $2.7 \pm 0.1 \mathrm{~mm}, 2.6 \pm 0.1 \mathrm{~mm}$ and $2.73 \pm 0.06 \mathrm{~mm}$ for Bacillus cereus, Staphylococcus aureus ATCC 6538 and Listeria monocytogenes CCM 4699, respectively, when LMPC-F has been used. The zones of inhibition are not significantly changed when $L M P C-F_{G}$ has been used. The radii of the zones of inhibition by LMPC-T-F and LMPC-T-F $\mathrm{F}_{\mathrm{G}}$ are represented in Figure 11B,C, respectively. For Bacillus cereus and Staphylococcus aureus, the zones of inhibition are higher with LMPC-T-F and LMPC-T- $\mathrm{F}_{\mathrm{G}}$, compared to LMPC-T. The zone of inhibition has an increasing trend with the increase in the concentration of trypsin for all microorganisms. The antibacterial activity of Lactobacillus bulgaricus and Streptococcus thermophilus against all mentioned microorganisms has been reported by other investigators $[118,119]$. During microbial fermentation, the reduction of $\mathrm{pH}$ [120] or the generation of new antibacterial peptides or bacteriocin $[120,121]$ may offer antibacterial activity against all mentioned microorganisms. It has been reported that the synergistic action of bacteriocin in a yogurt starter culture and an acidic $\mathrm{pH}$ offer antibacterial activity [122,123]. The biochemical characteristics of the bacteriocin produced by Streptococcus thermophilus are generally class IIa bacteriocin [123]. On the other hand, the biochemical characteristics of the bacteriocin produced by Lactobacillus bulgaricus are generally class IV bacteriocin [124]. It has been reported that the bacteriocin produced by Streptococcus thermophilus was less active against Staphylococcus aureus $[118,119,123]$ and Bacillus cereus $[118,119]$ than against Listeria monocytogenes. On the other hand, the bacteriocin produced by Lactobacillus bulgaricus was less active for inhibiting Staphylococcus aureus than Listeria monocytogenes and Bacillus cereus $[118,119]$. It is noted that the value of the zone of inhibition is not changed in a significant way in LMPC-T-F $\mathrm{G}_{\mathrm{G}}$ compared to LMPC-T-F.

\subsection{Immunogenicity}

Cow's milk allergy is a complex disorder because all milk proteins are involved in allergic responses and most of them contain multiple allergenic epitopes, categorized as linear (sequential) and conformational epitopes [24]. The major allergenic proteins in cow's milk are caseins, $\alpha$-lactalbumin and $\beta$-lactoglobulin [125]. Antigenicity and allergenicity in LMPC, LMPC-F, LMPC- $\mathrm{F}_{\mathrm{G}}$, LMPC-T, LMPC-T-F and LMPC-T- $\mathrm{F}_{\mathrm{G}}$ have been studied using $\mathrm{Rb}$ polyclonal antibodies, such as anti-casein, anti- $\alpha$-lactalbumin and anti- $\beta$-lactoglobulin, and cow's milk allergenic human pooled serum, respectively (Figure 12). 


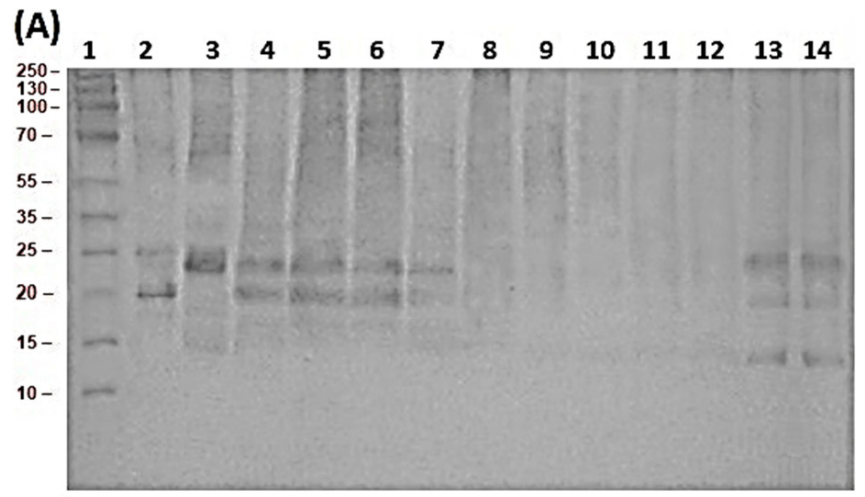

Lane 1: Marker proteins, Lane 2: Standard casein, Lane 3: LMPC, Lane 4: LMPC-T-0,008, Lane 5: LMPC-T-0,008-F, Lane 6: LMPC-T-0,008- $\mathrm{F}_{\mathrm{G}}$, Lane 7: LMPC-T-0,016, Lane 8: LMPC-T-0,016-F, Lane 9: LMPC-T-0,016- $\mathrm{F}_{\mathrm{G}}$, Lane 10: LMPC-T-0,032, Lane 11: LMPC-T-0,032-F, Lane 12: LMPC$\mathrm{T}-0,032-\mathrm{F}_{\mathrm{G}}$, Lane 13: LMPC-F, Lane 14: $\mathrm{LMPC}^{-\mathrm{F}_{\mathrm{G}}}$

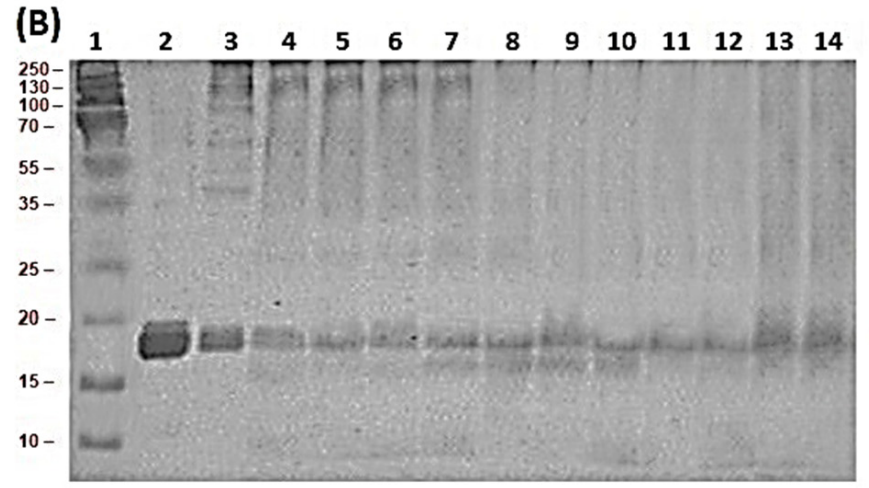

Lane 1: Marker proteins, Lane 2: Standard $\beta$-lactoglobulin, Lane 3: LMPC, Lane 4: LMPC-T-0,008, Lane 5: LMPC-T0,008-F, Lane 6: LMPC-T-0,008- $\mathrm{F}_{\mathrm{G}}$, Lane 7: LMPC-T-0,016, Lane 8: LMPC-T-0,016-F, Lane 9: LMPC-T-0,016-F $\mathrm{F}_{\mathrm{G}}$, Lane 10: LMPC-T-0,032, Lane 11: LMPC-T-0,032-F, Lane 12: LMPC-T-0,032-F $\mathrm{F}_{\mathrm{G}}$, Lane 13: LMPC-F, Lane 14: $\mathrm{LMPC}_{\mathrm{G}}$
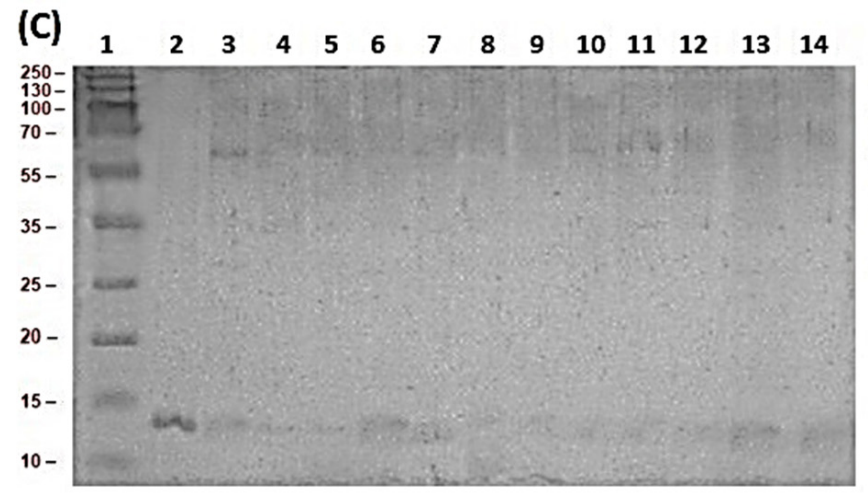

Lane 1: Marker proteins, Lane 2: Standard $\alpha$-Lactalbumin, Lane 3: LMPC, Lane 4: LMPC-T-0,008, Lane 5: LMPC-T0,008-F, Lane 6: LMPC-T-0,008- $\mathrm{F}_{\mathrm{G}}$, Lane 7: LMPC-T-0,016, Lane 8: LMPC-T-0,016-F, Lane 9: LMPC-T-0,016-F $\mathrm{F}_{\mathrm{G}}$, Lane 10: LMPC-T-0,032, Lane 11: LMPC-T-0,032-F, Lane 12: LMPC-T-0,032- $\mathrm{F}_{G}$, Lane 13: LMPC-F, Lane 14: LMPC-F $_{G}$

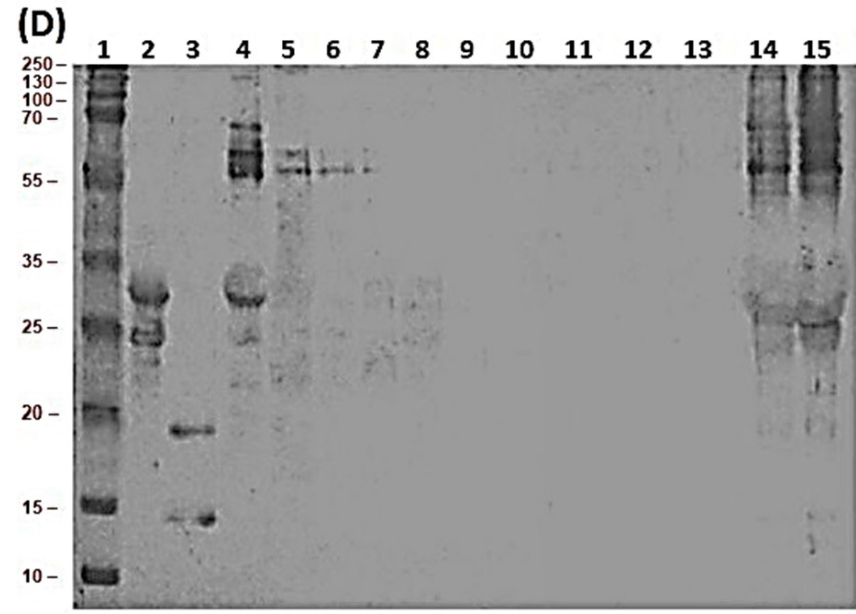

Lane 1: Marker proteins, Lane 2: Standard casein, Lane 3: Standard $\beta$-lactoglobulin and $\alpha$-Lactalbumin , Lane 4 : LMPC, Lane 5: LMPC-T-0,008, Lane 6: LMPC-T-0,008-F, Lane 7: LMPC-T-0,008- $F_{G}$, Lane 8: LMPC-T-0,016, Lane 9: LMPC-T-0,016-F, Lane 10: LMPC-T-0,016- $\mathrm{F}_{\mathrm{G}}$, Lane 11: LMPC-T-0,032, Lane 12: LMPC-T-0,032-F, Lane 13: LMPCT-0,032- $F_{G}$, Lane 14: LMPC-F, Lane 15: LMPC- $F_{G}$

Figure 12. Immunogenicity in LMPC, LMPC-F, LMPC-F ${ }_{G}, L M P C-T$, LMPC-T-F and LMPC-T-F . (A) Antigenicity against anti-casein $\mathrm{Rb}$ antibody, (B) antigenicity against anti- $\beta$-lactoglobulin $\mathrm{Rb}$ antibody, (C) antigenicity against anti- $\alpha$-lactalbumin $\mathrm{Rb}$ antibody, and (D) allergenicity against cow's milk allergenic human pooled serum. 


\subsubsection{Antigenicity}

The antigenicity of casein in all samples against the antibody $\mathrm{Rb}$ anti-casein is represented in Figure 12A. It can be seen that the casein in LMPC has antigenicity. Furthermore, some cross-reactivities with lactoferrin, lactoperoxidase, bovine serum albumin, $\beta$-lactoglobulin and $\alpha$-lactalbumin against the antibody $\mathrm{Rb}$ anti-casein are shown (lane 3). However, there is no antigenicity for lactoferrin, lactoperoxidase, bovine serum albumin and $\alpha$-lactalbumin, whereas the antigenicity of $\beta$-lactoglobulin is shown in LMPC-T-0.008. The antigenicity of casein is reduced (thin bands compared with casein in lane 3 ) in LMPC-T-0.008. Furthermore, a new antigenic peptide with a molecular weight of $\sim 23 \mathrm{kDa}$ appeared in LMPC-T-0.008 (lane 4). In the SDS-PAGE image, represented in Figure 4, a similar peptide band, probably a fragment of $\gamma$-casein, is observed. In LMPC-T-0.016, the antigenicity of residual casein, the fragment of $\gamma$-casein, and $\beta$-lactoglobulin are noted (lane 7). No antigenicity of any kind of casein is shown in LMPC-T-0.032 (lane 10). The antigenicity of casein, the fragment of $\gamma$-casein, and $\beta$-lactoglobulin in LMPC-T-0.008-F and LMPC-T-0.008- $\mathrm{F}_{\mathrm{G}}$ are still present. This can be explained by the fact that microbial hydrolysis is not able to remove the antigenic epitopes in the mentioned proteins, present in LMPC-T-0.008. However, the antigenicity of casein is present in LMPC-T-0.016, while no detectable antigenicity is noted in LMPC-T-0.016-F and LMPC-T-0.016- $\mathrm{F}_{\mathrm{G}}$. This can be explained by the fact that sequential tryptic and microbial hydrolysis of milk proteins are able to remove the antigenic epitopes in casein. The antigenicity of any protein is not shown in LMPC-T-0.032-F and LMPC-T-0.032- $\mathrm{F}_{\mathrm{G}}$. The antigenicity of casein, $\beta$-lactoglobulin and $\alpha$-lactalbumin in LMPC-F and LMPC- $\mathrm{F}_{\mathrm{G}}$ are shown. This signifies that they are resistant to proteolytic enzymes, as produced by lactic acid bacteria during fermentation.

The antigenicity of $\beta$-lactoglobulin in all samples against antibody $\mathrm{Rb}$ anti- $\beta$-lactoglobulin is represented in Figure 12B. It is noted that $\beta$-lactoglobulin in LMPC has antigenicity. Furthermore, some cross-reactivities with immunoglobulin, lactoferrin, lactoperoxidase, bovine serum albumin and the conjugate of $\beta$-lactoglobulin and $\alpha$-lactalbumin or conjugate of casein and $\alpha$-lactalbumin or dimer of $\beta$-lactoglobulin against the antibody Rb anti- $\beta$ lactoglobulin are shown. No cross-reactivities with casein and $\alpha$-lactalbumin against the antibody $\mathrm{Rb}$ anti- $\beta$-lactoglobulin were noted. However, the antigenicity of $\beta$-lactoglobulin is not significantly changed but the antigenicity in bovine serum albumin and conjugate of $\beta$-lactoglobulin and $\alpha$-lactalbumin, or the conjugate of casein and $\alpha$-lactalbumin, or the dimer of $\beta$-lactoglobulin are destroyed completely in LMPC-T-0.008 (lane 4). In LMPC-T-0.016, the antigenicity of immunoglobulin, lactoferrin and lactoperoxidase are not significantly changed but, due to the partial tryptic hydrolysis of $\beta$-lactoglobulin, a new antigenic peptide with a molecular weight of $\sim 17 \mathrm{kDa}$ is produced (lane 7). The antigenicity of immunoglobulin, lactoferrin and lactoperoxidase are significantly reduced, but the antigenicity of $\beta$-lactoglobulin and antigenic peptide with a molecular weight of $\sim 17 \mathrm{kDa}$ remained in LMPC-T-0.032 (lane 10). There are no significant changes to the antigenicity of immunoglobulin, lactoferrin, lactoperoxidase and $\beta$-lactoglobulin in LMPC-T-0.008-F and LMPC-T- $0.008-\mathrm{F}_{\mathrm{G}}$, compared to LMPC-T-0.008. This can be explained by the fact that microbial hydrolysis is not able to completely remove the antigenicity in the abovementioned proteins in LMPC-T-0.008. However, there are no significant changes to the antigenicity of $\beta$-lactoglobulin and $\beta$-lactoglobulin-derived peptides with a molecular weight of $\sim 17 \mathrm{kDa}$ in LMPC-T-0.016-F and LMPC-T-0.016- $\mathrm{F}_{\mathrm{G}}$ compared to LMPC-T-0.016; the antigenicity of immunoglobulin, lactoferrin and lactoperoxidase are completely removed. However, the antigenicity of the $\beta$-lactoglobulin-derived peptide with a molecular weight of $\sim 17 \mathrm{kDa}$ is removed, while the antigenicity of $\beta$-lactoglobulin is shown in LMPC-T-0.032-F and LMPC$\mathrm{T}-0.032-\mathrm{F}_{\mathrm{G}}$. It can be seen that the antigenicity of only $\beta$-lactoglobulin is present in LMPC-F and $\mathrm{LMPC}-\mathrm{F}_{\mathrm{G}}$. This signifies that microbial hydrolysis cannot remove the antigenicity of $\beta$-lactoglobulin; however, the antigenicity of immunoglobulin, lactoferrin, lactoperoxidase, bovine serum albumin and conjugate of $\beta$-lactoglobulin and $\alpha$-lactalbumin, or a conjugate of casein and $\alpha$-lactalbumin, or a dimer of $\beta$-lactoglobulin, as present in LMPC can be removed by microbial hydrolysis. 
The antigenicity of $\alpha$-lactalbumin in all samples against antibody $\mathrm{Rb}$ anti- $\alpha$-lactalbumin is shown in Figure 12C. It is noted that $\alpha$-lactalbumin in LMPC has antigenicity. Furthermore, some cross-reactivities with lactoferrin, lactoperoxidase and bovine serum albumin against the antibody $\mathrm{Rb}$ anti- $\alpha$-lactalbumin are shown. No cross-reactivities with casein and $\beta$-lactalbumin against the antibody $\mathrm{Rb}$ anti- $\alpha$-lactalbumin are shown (lane 3 ). It is notable that the antigenicity of $\alpha$-lactalbumin remained in LMPC-T-0.008. However, the antigenicity of bovine serum albumin is removed, but some antigenicity of lactoferrin and lactoperoxidase is still present in LMPC-T-0.008 (lane 4). A similar observation is noted for LMPC-T-0.016 and LMPC-T-0.032 (lane 7 and lane 10). In all cases, the antigenicity of $\alpha$-lactalbumin is not reduced after microbial hydrolysis, even after trypsin treatment. The antigenicity of $\alpha$-lactalbumin alone is present in LMPC-F and LMPC-F . This can be explained by the fact that microbial hydrolysis is not able to reduce the antigenicity of $\alpha$-lactalbumin in samples.

\subsubsection{Allergenicity}

In Figure 12D, the allergenicity of proteins and peptides in different samples is represented. In LMPC, immunoglobulin, lactoferrin, lactoperoxidase, bovine serum albumin, a dimer of $\beta$-lactoglobulin, conjugated $\kappa$-casein and $\alpha$-lactalbumin, or conjugated $\beta$-lactoglobulin and $\alpha$-lactalbumin, $\alpha$-casein, $\beta$-casein and $k$-casein have strong interactions with the antibody, whereas monomeric $\beta$-lactoglobulin has a weak interaction. No detectable interaction between monomeric $\alpha$-lactalbumin with the antibody is observed (Lane 4). During the preparation of UHT skimmed milk, the tertiary and quaternary configurations of $\beta$-lactoglobulin and $\alpha$-lactalbumin are turned to unfold due to heat treatment and, as a result, conformational epitopes in the protein structure are exposed [126,127]. In addition to this protein unfolding and aggregation, the Maillard reaction between the lysine residue in epitopes in $\beta$-lactoglobulin and $\alpha$-lactalbumin, and aldehyde/ketone group in lactose takes place, which may be responsible for reducing the allergenicity of $\beta$-lactoglobulin and $\alpha$-lactalbumin $[128,129]$. Furthermore, it has been reported that at $\mathrm{pH}$ 6.5, the denaturation temperature of $\alpha$-lactalbumin is $61^{\circ} \mathrm{C}$, whereas the denaturation temperatures of other major whey proteins, such as $\beta$-lactoglobulin and bovine serum albumin, are $75.9^{\circ} \mathrm{C}$ and $71.9^{\circ} \mathrm{C}$, respectively [130]. Protein folding and unfolding depend on temperature. The appearance of allergens in extended shelf-life milk and unheated natural milk is quite different from UHT milk. It has been shown that the denaturation of $\beta$-lactoglobulin and $\alpha$-lactalbumin is quite low in extended shelf-life milk compared to UHT milk [131]. Concerning the abovementioned biochemical phenomena, it may be supposed that during UHT skimmed-milk processing, $\alpha$-lactalbumin and $\beta$-lactoglobulin have lost their allergenic epitopes. However, in a clinical study with 20 children (median age 4 months), it was also found that the allergenic responses of $\alpha_{\mathrm{S} 1}$-casein, $\alpha_{\mathrm{S} 2}$-casein, $\beta$-casein, $\mathrm{k}$-casein, $\beta$-lactoglobulin, bovine serum albumin, Immunoglobulin-G heavy chain and lactoferrin were 55\%, 90\%, 15\%, 50\%, 45\%, 45\%, 95\%, and 50\%, respectively, while $\alpha$-lactalbumin did not offer any allergenic response in the Western-blotting (IgEimmunoreactive spots in the 2-DE maps) [132]. However, in another investigation with UHT skimmed milk and human pooled sera from cow's milk allergenic patients, it was found that lactoferrin, lactoperoxidase, and bovine serum albumin had a strong interaction with the antibody, while casein had a weaker interaction. No detectable allergenicity was found for $\beta$-lactoglobulin and $\alpha$-lactalbumin [133]. It is noted, however, that all proteins in LMPC, except $\alpha$-lactalbumin, have allergenicity, although their allergenicity is reduced in LMPC-T-0.008 (Lane 5). However, the remaining allergenicity in caseins and conjugated $\kappa$-casein and $\alpha$-lactoglobulin, or conjugated $\beta$-lactoglobulin and $\alpha$-lactalbumin, or the dimer of $\beta$-lactoglobulin is still present in LMPC-T-0.016 (Lane 8), whereas the allergenicity of the abovementioned proteins is almost lost in LMPC-T-0.032 (Lane 11). Comparing lane 5, lane 6 and lane 7, it is notable that the allergenicity of proteins in LMPC-T-0.008 is removed in a significant way after microbial hydrolysis. Interestingly, it can be seen that although allergenicity is present in LMPC-T-0.016 (lane 8), no detectable allergenicity is 
noted after microbial hydrolysis (lane 9 and lane 10). This can be explained by the fact that sequential tryptic and lactic acid bacteria fermentation can induce the degradation of allergens in milk proteins. Proteins and peptides with allergenicity are not detected in LMPC-T-0.032-F and LMPC-T-0.032- $\mathrm{F}_{\mathrm{G}}$. Similar to LMPC, allergenicity is shown in LMPC-F and LMPC- $\mathrm{F}_{\mathrm{G}}$. This can be explained by the fact that the allergenicity of proteins in LMPC cannot be removed by microbial fermentation.

Other pioneering researchers have also reported the degradation of allergenic epitopes in milk proteins and whey proteins by Lactobacillus bulgaricus and Streptococcus thermophilus [134-136]. The reduction of antigenicity in protein depends on (a) the presence of epitopes (linear and conformational epitopes) in the protein structure, (b) a native source of protein, (c) the type of enzyme, (d) the concentration of the enzyme, (e) hydrolysis time, and (f) the operating condition of hydrolysis [137]. This is the first attempt, to the best of our knowledge, to prepare peptides with an antioxidant capacity, angiotensin-converting enzyme inhibitory activity, antibacterial activity, and hypoallergenic properties from LMPC by sequential tryptic and microbial hydrolysis. Therefore, our results are not comparable with already published results.

\section{Conclusions}

In the present investigation, peptides with an antioxidant capacity, angiotensinconverting enzyme inhibitory activity, antibacterial activity, and hypoallergenic properties can be produced by the sequential tryptic and microbial hydrolysis of LMPC. For this study, LMPC was prepared from UHT skimmed cow's milk by a tubular nanofiltration membrane, placed in a crossflow membrane housing. The total filtration time, the reduction of permeate flux from initial flux, and the concentration of total protein in LMPC were $4.9 \mathrm{~h}, 22 \%$ and $56 \mathrm{~g} \cdot \mathrm{L}^{-1}$, respectively, in the case of the membrane filtration process with continuous feeding to maintain the volume reduction factor of 2 . Subsequently, the tryptic and microbial hydrolysis of LMPC were adopted. According to sodium dodecyl sulfatepolyacrylamide gel electrophoresis, the lower molecular weight of peptides was produced due to the trypsin treatment, in a concentration-dependent manner. The dissociation of the hydrogen bond with time progression during the tryptic hydrolysis reaction was noted in an aquagram because of the presence of a hydrogen bond in nucleophile and serine, and the formation of a tetrahedral enzyme-substrate intermediate with a hydrogen bond play a major role in the trypsin-catalyzed proteolysis reaction. The proteolytic system of lactic acid bacteria hydrolyzes the peptide bonds in proteins and, subsequently, peptides are transported to the biotic phase of lactic acid bacteria. Peptides are converted to different metabolites, such as amino acids, amines, sulfur compounds, and lactic acids, through different metabolic pathways. According to the aquagrams of microbial hydrolysis, there was a dissociation of the hydrogen bond in compounds during the initial period of fermentation and, subsequently, the formation of compounds with a hydrogen bond. The formation of compounds with a hydrogen bond was more noticeable when microbial hydrolysis was performed using glucose, due to the formation of nitrogenous metabolites and lactic acid, which can bind with proteins/peptides and water molecules. According to the electron donation capacity to reduce an oxidant (DPPH and FRAP assays), the antioxidant capacity was increased, due to the tryptic hydrolysis of LMPC. The non-competitive inhibition of angiotensin-converting enzyme activity was shown by LMPC-T, LMPC-T-F and LMPC$\mathrm{T}-\mathrm{F}_{\mathrm{G}}$. Due to the tryptic digestion of LMPC, antibacterial activity against Bacillus cereus and Staphylococcus aureus was shown. Furthermore, when LMPC was fermented with lactic acid bacteria, antimicrobial activity was additionally found against Listeria monocytogenes. Antibacterial activity against mentioned microbes was increased in LMPC-T-F compared to LMPC-T-F. The antigenicity of casein against $\mathrm{Rb}$ anti-casein was reduced due to the tryptic hydrolysis of LMPC. Furthermore, the antigenicity of casein against $\mathrm{Rb}$ anti-casein was reduced, due to microbial hydrolysis. The antigenicity of $\alpha$-lactalbumin and $\beta$-lactoglobulin was still detected after tryptic and microbial hydrolysis. Although allergenicity in LMPC with human pool serum was present after treatment with $0.016 \mathrm{~g} \cdot \mathrm{L}^{-1}$ 
of trypsin, no detectable allergenicity was found after fermentation. However, it was found that although glucose in microbial fermentation has an effect on the formation of peptides with an antioxidant capacity, angiotensin-converting enzyme inhibitory activity and antibacterial activity, it has no influence on the microbial hydrolysis of proteins and the reduction of antigenicity and allergenicity of proteins and peptides.

In this investigation, the concentration of proteins was determined by the Bradford assay. There are many limitations to this assay, including a preference for lysine and arginine and sensitivity to aromatic residues. These limitations make the assay inaccurate. In particular, the concentration of digested proteins, e.g., peptides with a molecular weight lower than 3000-5000 Da, may be underestimated. The present research was performed in a laboratory-scale setup. We believe that the results from the laboratory-scale setup will provide an initial idea of the production of bioactive peptides from LMPC on an industrial scale. It may be supposed that the present research may receive attention from both the academic sector and the food industry.

Supplementary Materials: The following are available online at https:/ / www.mdpi.com/article/10 $.3390 /$ pr9101688/s1.

Author Contributions: Conceptualization, A.N. and A.C.; methodology, A.N. and A.C.; software, D.T.N. and Z.K.; validation, A.N.; formal analysis, A.N., A.C., B.A.E. and D.T.N.; investigation, A.N., A.C., B.A.E. and D.T.N.; data curation, A.N., G.K., A.T., K.T., E.S. and A.K.; writing-original draft preparation, A.N., A.C., B.A.E. and D.T.N.; writing-review and editing, A.N. and G.V.; supervision, G.V.; project administration, K.P.-H., and G.V.; funding acquisition, A.N., A.C. and Z.K. All authors have read and agreed to the published version of the manuscript.

Funding: This research received no external funding.

Institutional Review Board Statement: Not applicable.

Informed Consent Statement: Not applicable.

Data Availability Statement: Not applicable.

Acknowledgments: Authors acknowledge the projects EFOP-3.6.3-VEKOP-16-2017-00005. A. Toth acknowledges the support of the GINOP-2.3.2-15-2016-00050. Project TKP2020-NKA-04 provided by the National Research, Development and Innovation Fund of Hungary, financed under the 20204.1.1-TKP2020 funding scheme is highly acknowledged. A. Csighy acknowledges Doctoral School of Food Science, Szent István University, Hungary. Z. Kovacs acknowledges the support of the New National Excellence Program of the Ministry for Innovation and Technology (ÚNKP-19-4-SZIE-27) and the Bolyai János Scholarship from the Hungarian Academy of Sciences.

Conflicts of Interest: The authors declare no conflict of interest.

\section{References}

1. Han, T.S.; Lean, M.E. A clinical perspective of obesity, metabolic syndrome and cardiovascular disease. JRSM Cardiovasc. Dis. 2016, 5, 204800401663337. [CrossRef]

2. Ferder, L.; Inserra, F.; Martínez-Maldonado, M. Inflammation and the metabolic syndrome: Role of angiotensin II and oxidative stress. Curr. Hypertens. Rep. 2006, 8, 191-198. [CrossRef] [PubMed]

3. Mancia, G.; Dell'Oro, R.; Quarti-Trevano, F.; Scopelliti, F.; Grassi, G. Angiotensin-sympathetic system interactions in cardiovascular and metabolic disease. J. Hypertens. 2006, 24, 51-56. [CrossRef] [PubMed]

4. Yamamoto, Y.; Gaynor, R.B. Therapeutic potential of inhibition of the NF- $\kappa$ B pathway in the treatment of inflammation and cancer. J. Clin. Investig. 2001, 107, 135-142. [CrossRef]

5. Tham, D.M.; Martin-McNulty, B.; Wang, Y.X.; Wilson, D.W.; Vergona, R.; Sullivan, M.E.; Dole, W.; Rutledge, J.C. Angiotensin II is associated with activation of NF-kB-mediated genes and downregulation of PPARs. Physiol. Genom. 2003, 11, 21-30. [CrossRef] [PubMed]

6. Kato, S.; Luyckx, V.A.; Ots, M.; Lee, K.W.; Ziai, F.; Troy, J.L.; Brenner, B.M.; Mackenzie, H.S. Renin-angiotensin blockade lowers MCP-1 expression in diabetic rats. Kidney Int. 1999, 56, 1037-1048. [CrossRef] [PubMed]

7. Hornig, B.; Landmesser, U.; Kohler, C.; Ahlersmann, D.; Spiekermann, S.; Christoph, A.; Tatge, H.; Drexler, H. Comparative effect of ACE inhibition and angiotensin II type 1 receptor antagonism on bioavailability of nitric oxide in patients with coronary artery disease: Role of superoxide dismutase. Circulation 2001, 103, 799-805. [CrossRef] [PubMed] 
8. Kimura, S.; Zhang, G.X.; Nishiyama, A.; Shokoji, T.; Yao, L.; Fan, Y.Y.; Rahman, M.; Abe, Y. Mitochondria-derived reactive oxygen species and vascular MAP kinases: Comparison of angiotensin II and diazoxide. Hypertension 2005, 45, 438-444. [CrossRef]

9. Zafari, A.M.; Ushio-fukai, M.; Akers, M.; Yin, Q.; Shah, A.; Harrison, D.G.; Taylor, W.R.; Griendling, K.K. Angiotensin II-Induced Vascular Hypertrophy. Hypertension 1998, 32, 488-495. [CrossRef]

10. Beckman, J.S.; Beckman, T.W.; Chen, J.; Marshall, P.A.; Freeman, B.A. Apparent hydroxyl radical production by peroxynitrite: Implications for endothelial injury from nitric oxide and superoxide. Proc. Natl. Acad. Sci. USA 1990, 87, 1620-1624. [CrossRef]

11. Wautier, M.P.; Chappey, O.; Corda, S.; Stern, D.M.; Schmidt, A.M.; Wautier, J.L. Activation of NADPH oxidase by AGE links oxidant stress to altered gene expression via RAGE. Am. J. Physiol.-Endocrinol. Metab. 2001, 280, E685-E694. [CrossRef] [PubMed]

12. Rocha, R.; Funder, J.W. The pathophysiology of aldosterone in the cardiovascular system. Ann. N. Y. Acad. Sci. 2002, 970, 89-100 [CrossRef] [PubMed]

13. Marcus, Y.; Shefer, G.; Stern, N. Adipose tissue renin-angiotensin-aldosterone system (RAAS) and progression of insulin resistance. Mol. Cell. Endocrinol. 2013, 378, 1-14. [CrossRef] [PubMed]

14. Ma, T.K.W.; Kam, K.K.H.; Yan, B.P.; Lam, Y.Y. Renin-angiotensin-aldosterone system blockade for cardiovascular diseases: Current status. Br. J. Pharmacol. 2010, 160, 1273-1292. [CrossRef] [PubMed]

15. Jahandideh, F.; Wu, J. Perspectives on the potential benefits of antihypertensive peptides towards metabolic syndrome. Int. J. Mol. Sci. 2020, 21, 2192. [CrossRef]

16. Sánchez-López, F.; Tasset, I.; Agüera, E.; Feijóo, M.; Fernández-Bolaños, R.; Sánchez, F.M.; Ruiz, M.C.; Cruz, A.H.; Lix Gascón, F.; Túnez, I. Oxidative stress and inflammation biomarkers in the blood of patients with huntington's disease. Neurol. Res. 2012, 34, 721-724. [CrossRef]

17. Kohanski, M.A.; Dwyer, D.J.; Collins, J.J. How antibiotics kill bacteria: From targets to networks. Nat. Rev. Microbiol. 2010, 8, 423-435. [CrossRef]

18. Neuenschwander, L.C.; Bittencourt, H.; Ribeiro, A.F.T.; Teixeira, A.L.; Teixeira, M.M.; Teixeira, J.C.; Nobre, V. Plasma levels of procalcitonin and eight additional inflammatory molecules in febrile neutropenic patients. Clinics 2011, 66, $1699-1705$.

19. Dwyer, D.J.; Belenky, P.A.; Yang, J.H.; Cody MacDonald, I.; Martell, J.D.; Takahashi, N.; Chan, C.T.Y.; Lobritz, M.A.; Braff, D.; Schwarz, E.G.; et al. Antibiotics induce redox-related physiological alterations as part of their lethality. Proc. Natl. Acad. Sci. USA 2014, 111, E2100-E2109. [CrossRef]

20. Chakrabarti, S.; Jahandideh, F.; Wu, J. Food-derived bioactive peptides on inflammation and oxidative stress. BioMed Res. Int. 2014, 2014, 608979. [CrossRef]

21. Oyinloye, B.E.; Adenowo, A.F.; Kappo, A.P. Reactive oxygen species, apoptosis, antimicrobial peptides and human inflammatory diseases. Pharmaceuticals 2015, 8, 151-175. [CrossRef]

22. Udenigwe, C.C.; Aluko, R.E. Food protein-derived bioactive peptides: Production, processing, and potential health benefits. J. Food Sci. 2012, 77, R11-R24. [CrossRef]

23. Nath, A.; Eren, B.A.; Csighy, A.; Pastorne-Huszar, K.; Kisko, G.; Abranko, L.; Toth, A.; Szerdahelyi, E.; Kovacs, Z.; Koris, A.; et al. Production of Liquid Milk Protein Concentrate with Antioxidant Capacity, Angiotensin Converting Enzyme Inhibitory Activity, Antibacterial Activity, and Hypoallergenic Property by Membrane Filtration and Enzymatic Modification of Proteins. Processes 2020, 8, 871. [CrossRef]

24. Vila, L.; Beyer, K.; Järvinen, K.M.; Chatchatee, P.; Bardina, L.; Sampson, H.A. Role of conformational and linear epitopes in the achievement of tolerance in cow's milk allergy. Clin. Exp. Allergy 2001, 31, 1599-1606. [CrossRef]

25. Muro Urista, C.; Álvarez Fernández, R.; Riera Rodriguez, F.; Arana Cuenca, A.; Téllez Jurado, A. Review: Production and functionality of active peptides from milk. Food Sci. Technol. Int. 2011, 17, 293-317. [CrossRef]

26. Crittenden, R.; Little, C.; Georgiou, G.; Forsyth, S.; Bennett, L. Cow's Milk Allergy: A Complex Disorder. Aust. J. Dairy Technol. 2007, 62, 62-71. [CrossRef] [PubMed]

27. Haddad, Z.H.; Kalra, V.; Verma, S. IgE antibodies to peptic and peptic-tryptic digests of betalactoglobulin: Significance in food hypersensitivity. Ann. Allergy 1979, 42, 368-371. [PubMed]

28. Colantuono, A.; D’Incecco, P.; Fortina, M.G.; Rosi, V.; Ricci, G.; Pellegrino, L. Milk substrates influence proteolytic activity of Pseudomonas fluorescens strains. Food Control 2020, 111, 107063. [CrossRef]

29. Troise, A.D.; Bandini, E.; De Donno, R.; Meijer, G.; Trezzi, M.; Fogliano, V. The quality of low lactose milk is affected by the side proteolytic activity of the lactase used in the production process. Food Res. Int. 2016, 89, 514-525. [CrossRef]

30. Li-Chan, E.C.Y. Bioactive peptides and protein hydrolysates: Research trends and challenges for application as nutraceuticals and functional food ingredients. Curr. Opin. Food Sci. 2015, 1, 28-37. [CrossRef]

31. Beshkova, D.; Simova, E.; Frengova, G.; Simov, Z. Production of flavour compounds by yogurt starter cultures. J. Ind. Microbiol. Biotechnol. 1998, 20, 180-186. [CrossRef]

32. Li, S.; Tang, S.; He, Q.; Hu, J.; Zheng, J. Changes in Proteolysis in Fermented Milk Produced by Streptococcus thermophilus in Co-Culture with Lactobacillus plantarum or Bifidobacterium animalis subsp. Lactis during Refrigerated Storage. Molecules 2019, 24, 3699. [CrossRef]

33. Laemmli, U.K. Cleavage of Structural Proteins during the Assembly of the Head of Bacteriophage T4. Nature 1970, 227, 680-685. [CrossRef] [PubMed]

34. Hajós, G.; Polgár, M.; Farkas, J. High-pressure effects on IgE immunoreactivity of proteins in a sausage batter. Innov. Food Sci. Emerg. Technol. 2004, 5, 443-449. [CrossRef] 
35. Bradford, M.M. A rapid and sensitive method for the quantitation of microgram quantities of protein utilizing the principle of protein-dye binding. Anal. Biochem. 1976, 72, 248-254. [CrossRef]

36. Benzie, I.F.F.; Strain, J.J. The Ferric Reducing Ability of Plasma (FRAP) as a Measure of "Antioxidant Power": The FRAP Assay. Anal. Biochem. 1996, 239, 70-76. [CrossRef]

37. Arfaoui, L. Total polyphenol content and radical scavenging activity of functional yogurt enriched with dates. Czech J. Food Sci. 2020, 38, 287-292. [CrossRef]

38. Fagyas, M.; Úri, K.; Siket, I.M.; Daragó, A.; Boczán, J.; Bányai, E.; Édes, I.; Papp, Z.; Tóth, A. New Perspectives in the ReninAngiotensin-Aldosterone System (RAAS) I: Endogenous Angiotensin Converting Enzyme (ACE) Inhibition. PLoS ONE 2014, 9, e87843.

39. Savitzky, A.; Golay, M.J.E. Smoothing and Differentiation of Data by Simplified Least Squares Procedures. Anal. Chem. 1964, 36, 1627-1639. [CrossRef]

40. Liu, Y.; Liu, Y.; Chen, Y.; Zhang, Y.; Shi, T.; Wang, J.; Hong, Y.; Fei, T.; Zhang, Y. The influence of spectral pretreatment on the selection of representative calibration samples for soil organic matter estimation using vis-NIR reflectance spectroscopy. Remote Sens. 2019, 11, 450. [CrossRef]

41. Tsenkova, R. Aquaphotomics: Water in the biological and aqueous world scrutinised with invisible light. Spectrosc. Eur. 2010, 22, 6-10.

42. R Core Team. R: A Language and Environment for Statistical Computing. 2017. Available online: https://www.R-project.org/ (accessed on 17 September 2021).

43. Kovacs, Z.; Pollner, B. Dedicated Aquaphotomics-Software R-Package „aquap2“ General Introduction and Workshop. In Proceedings of the Understanding Water in Biology at the 2nd International Symposium, Kobe, Japan, 26-29 November 2021; Kobe University, Faculty of Agriculture: Kobe, Japan, 2016.

44. Al-Mutwalli, S.A.; Dilaver, M.; Koseoglu-Imer, D.Y. Performance evaluation of ceramic membrane on ultrafiltration and diafiltration modes for efficient recovery of whey protein. J. Membr. Sci. Res. 2020, 6, 138-146.

45. Jeswan Singh, M.; Chandrapala, J.; Udabage, P.; McKinnon, I.; Augustin, M.A. Heat-induced changes in the properties of modified skim milks with different casein to whey protein ratios. J. Dairy Res. 2015, 82, 135-142. [CrossRef]

46. Galani, D.; Owusu Apenten, R.K. Heat-induced denaturation and aggregation of $\beta$-lactoglobulin: Kinetics of formation of hydrophobic and disulphide-linked aggregates. Int. J. Food Sci. Technol. 1999, 34, 467-476. [CrossRef]

47. Morr, C.V. Protein Aggregation in Conventional and Ultra High-Temparature Heated Skimmilk. J. Dairy Sci. 1969, 52, 1174-1180. [CrossRef]

48. Gezimati, J.; Singh, H.; Creamer, L.K. Aggregation and Gelation of Bovine $\beta$-Lactoglobulin, $\alpha$-Lactalbumin, and Serum Albumin. ACS Symp. Ser. 1996, 650, 113-123.

49. Jang, H.D.; Swaisgood, H.E. Disulfide Bond Formation Between Thermally Denatured $\beta$-Lactoglobulin and k-Casein in Casein Micelles. J. Dairy Sci. 1990, 73, 900-904. [CrossRef]

50. Vasbinder, A.J.; Van De Velde, F.; De Kruif, C.G. Gelation of casein-whey protein mixtures. J. Dairy Sci. 2004, 87, 1167-1176. [CrossRef]

51. Li, Y.; Dalgleish, D.; Corredig, M. Influence of heating treatment and membrane concentration on the formation of soluble aggregates. Food Res. Int. 2015, 76, 309-316. [CrossRef] [PubMed]

52. Sindhu, J.S.; Arora, S. Milk । Buffalo Milk. In Encyclopedia of Dairy Sciences, 2nd ed.; Fuquay, J.W., Ed.; Academic Press: San Diego, CA, USA, 2011; pp. 503-511. ISBN 978-0-12-374407-4.

53. Liu, E.; Zheng, H.; Shi, T.; Ye, L.; Konno, T.; Oda, M.; Shen, H.; Ji, Z.-S. Relationship between Lactobacillus bulgaricus and Streptococcus thermophilus under whey conditions: Focus on amino acid formation. Int. Dairy J. 2016, 56, 141-150. [CrossRef]

54. Tzvetkova, I.; Dalgalarrondo, M.; Danova, S.; Iliev, I.; Ivanova, I.; Chobert, J.M.; Haertlé, T. Hydrolysis of major dairy proteins by lactic acid bacteria from Bulgarian yogurts. J. Food Biochem. 2007, 31, 680-702. [CrossRef]

55. Tsenkova, R. Introduction: Aquaphotomics: Dynamic spectroscopy of aqueous and biological systems describes peculiarities of water. J. Near Infrared Spectrosc. 2009, 17, 303. [CrossRef]

56. Muncan, J.; Tsenkova, R. Aquaphotomics-From Innovative Knowledge to Integrative Platform in Science and Technology. Molecules 2019, 24, 2742. [CrossRef]

57. Perutka, Z.; Šebela, M. Pseudotrypsin: A Little-Known Trypsin Proteoform. Molecules 2018, 23, 2637. [CrossRef]

58. Weiner, S.J.; Seibel, G.L.; Kollman, P.A. The nature of enzyme catalysis in trypsin. Proc. Natl. Acad. Sci. USA 1986, 83, 649-653. [CrossRef]

59. Muncan, J.; Tei, K.; Tsenkova, R. Real-Time Monitoring of Yogurt Fermentation Process by Aquaphotomics Near-Infrared Spectroscopy. Sensors 2021, 21, 177. [CrossRef] [PubMed]

60. Lorenzen, P.; MEISEL, H. Influence of trypsin action in yoghurt milk on the release of caseinophosphopeptide-rich fractions and physical properties of the fermented products. Int. J. Dairy Technol. 2005, 58, 119-124. [CrossRef]

61. Okumura, M.; Yeh, L.I.; Myers, J.D.; Lee, Y.T. Infrared spectra of the solvated hydronium ion: Vibrational predissociation spectroscopy of mass-selected $\mathrm{H}_{3} \mathrm{O}^{+}$.cntdot. $\left(\mathrm{H}_{2} \mathrm{O}\right)$ n.cntdot. $\left(\mathrm{H}_{2}\right) \mathrm{m}$. J. Phys. Chem. 1990, 94, 3416-3427. [CrossRef]

62. Jiang, J.-C.; Wang, Y.-S.; Chang, H.-C.; Lin, S.H.; Lee, Y.T.; Niedner-Schatteburg, G.; Chang, H.-C. Infrared Spectra of $\mathrm{H}^{+}\left(\mathrm{H}_{2} \mathrm{O}\right)_{5-8}$ Clusters: Evidence for Symmetric Proton Hydration. J. Am. Chem. Soc. 2000, 122, 1398-1410. [CrossRef] 
63. Broyard, C.; Gaucheron, F. Modifications of structures and functions of caseins: A scientific and technological challenge. Dairy Sci. Technol. 2015, 95, 831-862. [CrossRef]

64. Savijoki, K.; Ingmer, H.; Varmanen, P. Proteolytic systems of lactic acid bacteria. Appl. Microbiol. Biotechnol. 2006, 71, 394-406. [CrossRef]

65. Pescuma, M.; Hébert, E.M.; Mozzi, F.; de Valdez, G.F. Hydrolysis of whey proteins by Lactobacillus acidophilus, Streptococcus thermophilus and Lactobacillus delbrueckii ssp. bulgaricus grown in a chemically defined medium. J. Appl. Microbiol. 2007, 103, 1738-1746. [CrossRef]

66. Zhang, C.; Zhang, Y.; Li, H.; Liu, X. The potential of proteins, hydrolysates and peptides as growth factors for Lactobacillus and Bifidobacterium: Current research and future perspectives. Food Funct. 2020, 11, 1946-1957. [CrossRef] [PubMed]

67. Kim, M.; Oh, S.; Imm, J.-Y. Buffering Capacity of Dairy Powders and Their Effect on Yoghurt Quality. Korean J. Food Sci. Anim. Resour. 2018, 38, 273-281. [PubMed]

68. Bouteille, R.; Gaudet, M.; Lecanu, B.; This, H. Monitoring lactic acid production during milk fermentation by in situ quantitative proton nuclear magnetic resonance spectroscopy. J. Dairy Sci. 2013, 96, 2071-2080. [CrossRef] [PubMed]

69. Chatham, J.C.; Forder, J.R. Lactic acid and protein interactions: Implications for the NMR visibility of lactate in biological systems. Biochim. Biophys. Acta-Gen. Subj. 1999, 1426, 177-184. [CrossRef]

70. Kanetro, B.; Slamet, A.; Wazyka, A. Effect of various solvent on the specific amino acids of black soybean (Glycine soja) sprout. IOP Conf. Ser. Earth Environ. Sci. 2018, 102, 12002. [CrossRef]

71. Kinsella, J.; Melachouris, N. Functional properties of proteins in foods: A survey. Crit. Rev. Food Sci. Nutr. 2009, 7, 219-280. [CrossRef]

72. Adler-Nissen, J. Enzymatic hydrolysis of proteins for increased solubility. J. Agric. Food Chem. 1976, 24, 1090-1093. [CrossRef]

73. Biasutti, E.; Vieira, C.; Capobiango, M.; Silva, V.; Silvestre, M. Study of Some Functional Properties of Casein: Effect of pH and Tryptic Hydrolysis. Int. J. Food Prop. 2007, 10, 173-183. [CrossRef]

74. Purohit, D.H.; Hassan, A.N.; Bhatia, E.; Zhang, X.; Dwivedi, C. Rheological, sensorial, and chemopreventive properties of milk fermented with exopolysaccharide-producing lactic cultures. J. Dairy Sci. 2009, 92, 847-856. [CrossRef]

75. Gezginc, Y.; Topcal, F.; Comertpay, S.; Akyol, I. Quantitative analysis of the lactic acid and acetaldehyde produced by Streptococcus thermophilus and Lactobacillus bulgaricus strains isolated from traditional Turkish yogurts using HPLC. J. Dairy Sci. 2015, 98, 1426-1434. [CrossRef] [PubMed]

76. Bills, D.D.; Yang, C.S.; Morgan, M.E.; Bodyfelt, F.W. Effect of Sucrose on the Production of Acetaldehyde and Acids by Yogurt Culture Bacteria. J. Dairy Sci. 1972, 55, 1570-1573. [CrossRef]

77. Jamshidian, M.; Arab-Tehrany, E.; Imran, M.; Jacquot, M.; Desobry, S. Poly-Lactic Acid: Production, Applications, Nanocomposites, and Release Studies. Compr. Rev. Food Sci. Food Saf. 2010, 9, 552-571. [CrossRef] [PubMed]

78. Williams, P. Influence of Water on Prediction of Composition and Quality Factors: The Aquaphotomics of Low Moisture Agricultural Materials. J. Near Infrared Spectrosc. 2009, 17, 315-328. [CrossRef]

79. Neto, Y.A.A.H.; Rosa, J.C.; Cabral, H. Peptides with antioxidant properties identified from casein, whey, and egg albumin hydrolysates generated by two novel fungal proteases. Prep. Biochem. Biotechnol. 2019, 49, 639-648. [CrossRef]

80. Bamdad, F.; Shin, S.H.; Suh, J.-W.; Nimalaratne, C.; Sunwoo, H. Anti-Inflammatory and Antioxidant Properties of Casein Hydrolysate Produced Using High Hydrostatic Pressure Combined with Proteolytic Enzymes. Molecules 2017, $22,609$.

81. Abd El-Fattah, A.; Sakr, S.; El-Dieb, S.; Elkashef, H. Bioactive peptides with ACE-I and antioxidant activity produced from milk proteolysis. Int. J. Food Prop. 2017, 20, 3033-3042. [CrossRef]

82. Sabeena Farvin, K.H.; Baron, C.P.; Nielsen, N.S.; Jacobsen, C. Antioxidant activity of yoghurt peptides: Part 1-in vitro assays and evaluation in $\omega$-3 enriched milk. Food Chem. 2010, 123, 1081-1089. [CrossRef]

83. Sabeena Farvin, K.H.; Baron, C.P.; Nielsen, N.S.; Otte, J.; Jacobsen, C. Antioxidant activity of yoghurt peptides: Part 2Characterisation of peptide fractions. Food Chem. 2010, 123, 1090-1097. [CrossRef]

84. Yilmaz-Ersan, L.; Ozcan, T.; Akpinar-Bayizit, A.; Sahin, S. Comparison of antioxidant capacity of cow and ewe milk kefirs. J. Dairy Sci. 2018, 101, 3788-3798.

85. Aloğlu, H.; Oner, Z. Determination of antioxidant activity of bioactive peptide fractions obtained from yogurt. J. Dairy Sci. 2011, 94, 5305-5314. [CrossRef]

86. Courtin, P.; Rul, F. Interactions between microorganisms in a simple ecosystem: Yogurt bacteria as a study model. Le Lait 2003, 84, 125-134. [CrossRef]

87. Schieber, A.; Brückner, H. Characterization of oligo- and polypeptides isolated from yoghurt. Eur. Food Res. Technol. 2000, 210, 310-313.

88. López-Fandiño, R.; Otte, J.; van Camp, J. Physiological, chemical and technological aspects of milk-protein-derived peptides with antihypertensive and ACE-inhibitory activity. Int. Dairy J. 2006, 16, 1277-1293. [CrossRef] [PubMed]

89. Wang, T.; Xu, Z.; Lu, S.; Xin, M.; Kong, J. Effects of glutathione on acid stress resistance and symbiosis between Streptococcus thermophilus and Lactobacillus delbrueckii subsp. bulgaricus. Int. Dairy J. 2016, 61, 22-28. [CrossRef]

90. Pophaly, S.D.; Poonam, S.; Pophaly, S.D.; Kapila, S.; Nanda, D.K.; Tomar, S.K.; Singh, R. Glutathione biosynthesis and activity of dependent enzymes in food-grade lactic acid bacteria harbouring multidomain bifunctional fusion gene (gshF). J. Appl. Microbiol. 2017, 123, 194-203. [CrossRef] [PubMed] 
91. Ramchandran, L.; Shah, N.P. Characterization of functional, biochemical and textural properties of synbiotic low-fat yogurts during refrigerated storage. LWT-Food Sci. Technol. 2010, 43, 819-827. [CrossRef]

92. Ramchandran, L.; Shah, N.P. Effect of exopolysaccharides on the proteolytic and angiotensin-I converting enzyme-inhibitory activities and textural and rheological properties of low-fat yogurt during refrigerated storage. J. Dairy Sci. 2009, 92, 895-906. [CrossRef]

93. Wang, C.; Tu, M.; Wu, D.; Chen, H.; Chen, C.; Wang, Z.; Jiang, L. Identification of an ACE-Inhibitory Peptide from Walnut Protein and Its Evaluation of the Inhibitory Mechanism. Int. J. Mol. Sci. 2018, 19, 1156. [CrossRef]

94. Vermeirssen, V.; Van Camp, J.; Decroos, K.; Van Wijmelbeke, L.; Verstraete, W. The impact of fermentation and in vitro digestion on the formation of angiotensin-I-converting enzyme inhibitory activity from pea and whey protein. J. Dairy Sci. 2003, 86, 429-438 [CrossRef]

95. Manso, M.A.; López-Fandiño, R. Angiotensin I converting enzyme-inhibitory activity of bovine, ovine, and caprine kappa-casein macropeptides and their tryptic hydrolysates. J. Food Prot. 2003, 66, 1686-1692. [CrossRef] [PubMed]

96. Pihlanto-Leppälä, A.; Koskinen, P.; Piilola, K.; Tupasela, T.; Korhonen, H. Angiotensin I-converting enzyme inhibitory properties of whey protein digests: Concentration and characterization of active peptides. J. Dairy Res. 2000, 67, 53-64. [CrossRef] [PubMed]

97. Mullally, M.M.; Meisel, H.; FitzGerald, R.J. Synthetic peptides corresponding to alpha-lactalbumin and beta-lactoglobulin sequences with angiotensin-I-converting enzyme inhibitory activity. Biol. Chem.-Hoppe Seyler 1996, 377, $259-260$.

98. Asoodeh, A.; Homayouni-Tabrizi, M.; Shabestarian, H.; Emtenani, S.; Emtenani, S. Biochemical characterization of a novel antioxidant and angiotensin I-converting enzyme inhibitory peptide from Struthio camelus egg white protein hydrolysis. J. Food Drug Anal. 2016, 24, 332-342. [CrossRef]

99. Cheung, H.S.; Wang, F.L.; Ondetti, M.A.; Sabo, E.F.; Cushman, D.W. Binding of peptide substrates and inhibitors of angiotensinconverting enzyme. Importance of the COOH-terminal dipeptide sequence. J. Biol. Chem. 1980, 255, 401-407. [CrossRef]

100. Hernández-Ledesma, B.; Amigo, L.; Ramos, M.; Recio, I. Angiotensin converting enzyme inhibitory activity in commercial fermented products. Formation of peptides under simulated gastrointestinal digestion. J. Agric. Food Chem. 2004, 52, 1504-1510. [CrossRef] [PubMed]

101. Minervini, F.; Algaron, F.; Rizzello, C.G.; Fox, P.F.; Monnet, V.; Gobbetti, M. Angiotensin I-converting-enzyme-inhibitory and antibacterial peptides from Lactobacillus helveticus PR4 proteinase-hydrolyzed caseins of milk from six species. Appl. Environ. Microbiol. 2003, 69, 5297-5305. [CrossRef]

102. Shakerian, M.; Razavi, S.H.; Ziai, S.A.; Khodaiyan, F.; Yarmand, M.S.; Moayedi, A. Proteolytic and ACE-inhibitory activities of probiotic yogurt containing non-viable bacteria as affected by different levels of fat, inulin and starter culture. J. Food Sci. Technol. 2015, 52, 2428-2433. [CrossRef]

103. Fagyas, M.; Úri, K.; Siket, I.M.; Fülöp, G.Á.; Csató, V.; Daragó, A.; Boczán, J.; Bányai, E.; Szentkirályi, I.E.; Maros, T.M.; et al. New perspectives in the renin-angiotensin-aldosterone system (RAAS) II: Albumin suppresses angiotensin converting enzyme (ACE) activity in human. PLoS ONE 2014, 9, e87844. [CrossRef] [PubMed]

104. Guang, C.; Phillips, R.D. Plant food-derived Angiotensin I converting enzyme inhibitory peptides. J. Agric. Food Chem. 2009, 57, 5113-5120. [CrossRef] [PubMed]

105. Vallabha, V.; Kaultiku, P. Antihypertensive Peptides Derived from Soy Protein by Fermentation. Int. J. Pept. Res. Ther. 2014, 20, 161. [CrossRef]

106. Medeiros, V.; Rainha, N.; Paiva, L.; Lima, E.; Baptista, J. Bovine Milk Formula Based on Partial Hydrolysis of Caseins by Bromelain Enzyme: Better Digestibility and Angiotensin-Converting Enzyme-Inhibitory Properties. Int. J. Food Prop. 2014, 17, 806-817. [CrossRef]

107. Wang, R.; Han, Z.; Ji, R.; Xiao, Y.; Si, R.; Guo, F.; He, J.; Hai, L.; Ming, L.; Yi, L. Antibacterial Activity of Trypsin-Hydrolyzed Camel and Cow Whey and Their Fractions. Animals 2020, 10, 337. [CrossRef]

108. Bruni, N.; Capucchio, M.T.; Biasibetti, E.; Pessione, E.; Cirrincione, S.; Giraudo, L.; Corona, A.; Dosio, F. Antimicrobial Activity of Lactoferrin-Related Peptides and Applications in Human and Veterinary Medicine. Molecules 2016, 21, 752. [CrossRef]

109. Silva, A.; Honjoya, E.; Cardoso, S.; Souza, C.; Costa, M.; Santana, E.; Aragon-Alegro, L. Antimicrobial action of lactoferrin on Staphylococcus aureus inoculated in Minas frescal cheese. Arch. Latinoam. Nutr. 2012, 62, 68-72.

110. Seifu, E.; Buys, E.M.; Donkin, E.F. Significance of the lactoperoxidase system in the dairy industry and its potential applications: A review. Trends Food Sci. Technol. 2005, 16, 137-154. [CrossRef]

111. Davidson, P.M.; Taylor, T.M.; Schmidt, S.E. Chemical Preservatives and Natural Antimicrobial Compounds. In Food Microbiology: Fundamentals and Frontiers; John Wiley \& Sons, Ltd.: Hoboken, NJ, USA, 2012; pp. 765-801. ISBN 9781683670582.

112. Travkova, O.G.; Moehwald, H.; Brezesinski, G. The interaction of antimicrobial peptides with membranes. Adv. Colloid Interface Sci. 2017, 247, 521-532. [CrossRef]

113. Patrzykat, A.; Douglas, S.E. Antimicrobial peptides: Cooperative approaches to protection. Protein Pept. Lett. 2005, 12, 19-25. [CrossRef]

114. Matin, M.; Monnai, M.; Otani, H. Isolation and Characterization of a Cytotoxic Pentapeptide, k-casecidin, from Bovine k-casein Digested with Bovine Trypsin. Nihon Chikusan Gakkaiho 2000, 71, 197-207. [CrossRef]

115. Pellegrini, A.; Thomas, U.; Bramaz, N.; Hunziker, P.; von Fellenberg, R. Isolation and identification of three bactericidal domains in the bovine $\alpha$-lactalbumin molecule. Biochim. Biophys. Acta-Gen. Subj. 1999, 1426, 439-448. [CrossRef] 
116. Pellegrini, A.; Dettling, C.; Thomas, U.; Hunziker, P. Isolation and characterization of four bactericidal domains in the bovine ß-lactoglobulin. Biochim. Biophys. Acta-Gen. Subj. 2001, 1526, 131-140. [CrossRef]

117. Zucht, H.D.; Raida, M.; Adermann, K.; Mägert, H.J.; Forssmann, W.G. Casocidin-I: A casein- $\alpha_{\mathrm{s} 2}$ derived peptide exhibits antibacterial activity. FEBS Lett. 1995, 372, 185-188. [CrossRef]

118. Akpinar, A.; Yerlikaya, O.; Kiliç, S. Antimicrobial activity and antibiotic resistance of Lactobacillus delbrueckii ssp bulgaricus and Streptococcus thermophilus strain isolated from Turkish homemade yoghurts. Afr. J. Microbiol. Res. 2011, 5, 675-682.

119. Yerlikaya, O.; Saygili, D.; Akpinar, A. Evaluation of antimicrobial activity and antibiotic susceptibility profiles of Lactobacillus delbrueckii subsp. bulgaricus and Streptococcus thermophilus strains isolated from commercial yoghurt starter cultures. Ciênc. Tecnol. Aliment. 2020, 41, 418-425. [CrossRef]

120. Al-Nabulsi, A.A.; Olaimat, A.N.; Osaili, T.M.; Ayyash, M.M.; Abushelaibi, A.; Jaradat, Z.W.; Shaker, R.; Al-Taani, M.; Holley, R.A. Behavior of Escherichia coli O157:H7 and Listeria monocytogenes during fermentation and storage of camel yogurt. J. Dairy Sci. 2016, 99, 1802-1811. [CrossRef]

121. Gomez, S.; Cosson, C.; Deschamps, A.M. Evidence for a bacteriocin-like substance produced by a new strain of Streptococcus sp., inhibitory to gram-positive food-borne pathogens. Res. Microbiol. 1997, 148, 757-766. [CrossRef]

122. Massa, S.; Trovatelli, L.D.; Canganella, F. Survival of Listeria monocytogenes in yogurt during storage at $4{ }^{\circ} \mathrm{C}$. Lett. Appl. Microbiol. 1991, 13, 112-114. [CrossRef]

123. Benkerroum, N.; Oubel, H.; Mimoun, L. Behavior of Listeria monocytogenes and Staphylococcus aureus in Yogurt Fermented with a Bacteriocin-Producing Thermophilic Starter. J. Food Prot. 2002, 65, 799-805. [CrossRef]

124. Miteva, V.; Ivanova, I.; Budakov, I.; Pantev, A.; Stefanova, T.; Danova, S.; Moncheva, P.; Mitev, V.; Dousset, X.; Boyaval, P. Detection and characterization of a novel antibacterial substance produced by a Lactobacillus delbrueckii strain 1043. J. Appl. Microbiol. 1998, 85, 603-614. [CrossRef]

125. Wal, J.-M. Bovine milk allergenicity. Ann. Allergy Asthma Immunol. 2004, 93, S2-S11. [CrossRef]

126. Fritsché, R. Role for technology in dairy allergy. Aust. J. Dairy Technol. 2003, 58, 89-91.

127. Bu, G.; Luo, Y.; Zheng, Z.; Zheng, H. Effect of heat treatment on the antigenicity of bovine $\alpha$-lactalbumin and $\beta$-lactoglobulin in whey protein isolate. Food Agric. Immunol. 2009, 20, 195-206. [CrossRef]

128. Xu, Q.; Shi, J.; Yao, M.; Jiang, M.; Luo, Y. Effects of heat treatment on the antigenicity of four milk proteins in milk protein concentrates. Food Agric. Immunol. 2015, 27, 401-413. [CrossRef]

129. Liu, F.; Teodorowicz, M.; van Boekel, M.A.J.S.; Wichers, H.J.; Hettinga, K.A. The decrease in the IgG-binding capacity of intensively dry heated whey proteins is associated with intense Maillard reaction, structural changes of the proteins and formation of RAGE-ligands. Food Funct. 2016, 7, 239-249. [CrossRef] [PubMed]

130. Antoine, E.; Souza, C. Study by Differential Scanning Calorimetry of the Thermal Stability of Whey Proteins Concentrate. Biotechnology 2007, 6, 431-435. [CrossRef]

131. Deeth, H. Optimum Thermal Processing for Extended Shelf-Life (ESL) Milk. Foods 2017, 6, 102. [CrossRef]

132. Natale, M.; Bisson, C.; Monti, G.; Peltran, A.; Garoffo, L.P.; Valentini, S.; Fabris, C.; Bertino, E.; Coscia, A.; Conti, A. Cow's milk allergens identification by two-dimensional immunoblotting and mass spectrometry. Mol. Nutr. Food Res. 2004, 48, 363-369. [CrossRef] [PubMed]

133. Wróblewska, B.; Kaliszewska, A. Cow's milk proteins immunoreactivity and allergenicity in processed food. Czech J. Food Sci. 2018, 30, 211-219. [CrossRef]

134. Pescuma, M.; Hébert, E.M.; Rabesona, H.; Drouet, M.; Choiset, Y.; Haertlé, T.; Mozzi, F.; de Valdez, G.F.; Chobert, J.-M. Proteolytic action of Lactobacillus delbrueckii subsp. bulgaricus CRL 656 reduces antigenic response to bovine $\beta$-lactoglobulin. Food Chem. 2011, 127, 487-492. [CrossRef]

135. Bu, G.; Luo, Y.; Zhang, Y.; Chen, F. Effects of fermentation by lactic acid bacteria on the antigenicity of bovine whey proteins. J. Sci. Food Agric. 2010, 90, 2015-2020. [CrossRef] [PubMed]

136. Kleber, N.; Weyrich, U.; Hinrichs, J. Screening of lactic acid bacteria with potential to reduce antigenic response of $\beta$-lactoglobulin bovine skim milk and sweet whey. Innov. Food Sci. Emerg. Technol. 2006, 7, 233-238. [CrossRef]

137. Abd El-Salam, M.; El-Shibiny, S. Reduction of Milk Protein Antigenicity by Enzymatic Hydrolysis and Fermentation. A Review. Food Rev. Int. 2019, 37, 276-295. [CrossRef] 